\title{
Ovarian cancer stem cells: still an elusive entity?
}

\author{
Michela Lupia and Ugo Cavallaro* (1)
}

\begin{abstract}
The cancer stem cell (CSC) model proposes that tumor development and progression are fueled and sustained by undifferentiated cancer cells, endowed with self-renewal and tumor-initiating capacity. Ovarian carcinoma, based on its biological features and clinical evolution, appears as a prototypical example of CSC-driven disease. Indeed, ovarian cancer stem cells (OCSC) would account not only for the primary tumor growth, the peritoneal spread and the relapse, but also for the development of chemoresistance, thus having profound implication for the treatment of this deadly disease. In the last decade, an increasing body of experimental evidence has supported the existence of OCSC and their pathogenic role in the disease. Nevertheless, the identification of OCSC and the definition of their phenotypical and functional traits have proven quite challenging, mainly because of the heterogeneity of the disease and of the difficulties in establishing reliable biological models. A deeper understanding of OCSC pathobiology will shed light on the mechanisms that underlie the clinical behaviour of OC. In addition, it will favour the design of innovative treatment regimens that, on one hand, would counteract the resistance to conventional chemotherapy, and, on the other, would aim at the eradication of OC through the elimination of its CSC component.
\end{abstract}

\section{Background}

\section{Ovarian cancer}

Epithelial ovarian carcinoma $(\mathrm{OC})$ is the most lethal gynaecological neoplasm. Approximately 240,000 new cases of OC are diagnosed every year, with 140,000 patients succumbing to the disease [1]. The 5-year overall survival is below $45 \%$ and it decreases to $25 \%$ among patients with advanced OC [2]. There are several factors that contribute to the high death-to-incidence ratio of this disease. First, due to the fact that early-stage $\mathrm{OC}$ is not associated with specific symptoms, $70 \%$ of the cases are diagnosed when the tumor has already spread into the abdominal cavity [3]. Second, even after primary debulking surgery and adjuvant chemotherapy with carboplatin/paclitaxel (see below), the vast majority of patients with advanced $\mathrm{OC}$ experience tumor recurrence, in many cases within 2 years from the diagnosis [4]. Third, in contrast to the primary tumor, recurrent disease often develops resistance to conventional

\footnotetext{
* Correspondence: ugo.cavallaro@ieo.it

Unit of Gynecological Oncology Research, European Institute of Oncology, Via G. Ripamonti 435, I-20141 Milan, Italy
}

chemotherapy, resulting in a very poor cure rate and accounting for the high lethality of OC.

The definition of OC encompasses a wide range of neoplasms that are very distinct for their histopathological traits as well as for their origin, clinical evolution and response to treatment. These different histotypes can be grouped into two main classes: Type I and Type II. The former group, characterized by an indolent clinical course and general confinement to the ovary, includes low-grade and borderline serous, low-grade endometrioid, clear cell, mucinous and transitional (Brenner) carcinomas. These tumors often exhibit mutations in specific genes that include KRAS, BRAF, PTEN, PIK3CA, CTNNB1, ARID1A, and are characterized by microsatellite instability and genomic stability. Type II OC, instead, includes high-grade serous carcinoma, undifferentiated carcinoma and carcinosarcoma, present at advanced stage and exhibit highly aggressive behaviour. These tumors almost invariably have TP53 mutations, frequent inherited and somatic mutations in BRCA1 and $B R C A 2$ genes, and genomic (chromosomal) instability $[5,6]$. The most frequent form of type II OC is highgrade serous carcinoma (HGSC), which accounts for about $75 \%$ of all OC cases. HGSC is also very aggressive 
and causes $70-80 \%$ of all deaths among OC patients [7], thus representing the most outstanding clinical challenge in gynaecological oncology.

Following primary cytoreduction, patients with Type II tumors undergo adjuvant treatments with platinumbased compounds, often in combination with taxanes. Cyclophosphamide and liposomal doxorubicin are additional chemotherapeutics used in OC treatment. While these drugs have represented the standard of care for the last 40 years (platinum-based therapy was introduced in the late 1970s), other approaches are being intensively investigated especially in combination regimens. For example, the anti-angiogenic agent bevacizumab, an antibody that antagonizes vascular endothelial growth factor, has entered the clinical practice as a firstline therapy in combination to carboplatin/paclitaxel as well as maintenance therapy. Other anti-angiogenic compounds with different mechanisms of action are under clinical investigation [8] and the tyrosine kinase inhibitor cediranib, in particular, prolongs significantly the progression-free survival in platinum-sensitive ovarian cancer [9].

Other therapies that are currently being tested include poly-ADP-ribose polymerase (PARP) inhibitors, which gave promising results in homologous recombinationdeficient OC $[10,11]$, and inhibitors of immune checkpoints (CTLA-4, PD-1, PD-L1) that, however, so far have shown only limited efficacy [12].

\section{Main text}

\section{Ovarian cancer: biological challenges}

As mentioned above, OC defines a number of diseases with different clinical evolution. Such heterogeneity is the result of sharp differences in the biology that underlies the development and the natural history of the OC variants. First, in contrast to the classical view that the different $\mathrm{OC}$ hystotypes derive from metaplastic changes of one single tissue, the ovarian surface epithelium (OSE) $[13,14]$, it has become increasingly clear that only a subset of epithelial OC actually develops within the OSE, while most OC variants originate in non-ovarian districts [15]. As outlined in greater detail below (see "The normal counterpart of OCSC"), this is best exemplified by HGSC, for which clinical, pathological, and experimental evidence supports the fallopian tube as a frequent site of origin [16-19].

OC poses outstanding challenges also with regard to its genomic profile. Indeed, besides the inherent molecular heterogeneity associated with the different tumor histotypes (for example the genomic stability of low-grade serous OC vs. the striking instability of HGSC [3]), the picture is quite fuzzy also within the single variants. Again, HGSC offers a prototypical example in this context: indeed, with the exception of TP53 that is mutated in virtually all HGSC, there are no mutations in oncogenes or tumor suppressor genes that occur frequently enough to be considered as a hallmark of the disease [20]. Rather, HGSC displays high rate of copy number variations and chromosomal instability which can then result in the inactivation of tumor suppressing pathways as well as in the acquisition of chemoresistance [21].

These and other challenges reflect the difficulties in developing reliable and faithful experimental models of OC. While this has been particularly evident with regard to animal models, as comprehensively reviewed elsewhere [22], recent data have also questioned most of the cell lines that have been used for decades in OC research. Indeed, a number of studies have shown that the majority of classical OC cell lines perform poorly in recapitulating either the molecular pathogenesis and/or the histopathological traits of their supposed tumor of origin [23-26]. Therefore, while these cell lines have provided useful experimental platforms (and are still employed as OC models), the data obtained should be re-interpreted in the light of these re-classification efforts, elucidating in particular to what extent the knowledge acquired can be transferred to the real disease. The studies mentioned above also highlighted a number of OC-derived cell lines that, in spite of their limited use in the past, do recapitulate the genomic profile of their tumor of origin. However, xenograft experiments on some of the cell lines with the highest genomic fidelity highlighted their poor tumor take in recipient mice [27], which may become an issue for their use as preclinical models.

All these challenges related to the OC biology and to its representation should be taken into account when OC models (either in vivo or in vitro) are employed for the identification and characterization of cancer stem cells, and they underscore the requirement for careful validation of the results in clinically relevant settings.

\section{Cancer stem cells: general concepts}

Cancer stem cells (CSC) share several biological features with normal SC, including self-renewal, resistance to apoptosis induced by loss of anchorage, and ability to undergo differentiation through asymmetric cell division. In addition, a defining property restricted to CSC is their ability, upon transplantation into a recipient organism, to generate a tumor in which the hierarchical organization and the heterogeneity of the original disease are recapitulated. Based on this function, CSC are also commonly called tumor-initiating cells [28]. In this review, we will refer to tumor initiation as the ability of a single CSC to form a xenograft representative of the parental tumor. Notwithstanding such a tumorigenic capacity, it should be clarified that the CSC concept is distinct from that of the cell-of-origin. The latter, indeed, 
refers to the cell from which a tumor has derived, that is the cell type that was first hit by an oncogenic alteration, an event that does not necessarily entails the acquisition of CSC traits [29].

CSC are often resistant to chemotherapeutic and radiation treatments, mainly due to their quiescent state and to the expression of molecular pumps that efflux the drugs and of intracellular scavengers such as ALDH1 (see below). While chemoresistance per se is not a defining feature of CSC, it has outstanding implications for the clinical evolution of tumors, for example with regard to recurrence after treatment [30].

Finally, another feature that has been frequently reported in CSC is their acquisition of mesenchymal traits through the so-called epithelial-mesenchymal transition (EMT). EMT was initially characterized as a process that confers migratory and invasive properties to cells [31]. Thereafter, it was found that EMT also endows epithelial cells with stemness-associated properties and, in the case of cancer cells, with increased tumorigenic potential and chemoresistance [32, 33], as it has also been proposed in OC [34]. After the pioneering studies in mammary cells [35], the relationship between EMT and CSC has received further support in several experimental models. In particular, EMT as well as its reversal (mesenchymalepithelial transition, MET) have been found to be highly dynamic processes in tumor cells, and cancer stemness seems associated with a "partial EMT" phenotype rather than full-blown EMT [33, 36, 37]. This concept is tightly linked with that of CSC plasticity, which postulates that CSC can switch between different states (including nonstem states) [38]. Along this line, partial EMT would represent one of such transitional phenotypes that is compatible with (and may contribute to) the function of CSC.

Biological properties such as self-renewal, asymmetric division, EMT, cancer initiation and differentiation capacity are intrinsically difficult to assess within the original tumor. Therefore, a number of surrogate assays have been developed [39]: for instance, sphere formation under non-adherent conditions reflects the clonogenic potential of CSC (and of normal SC as well) and, upon serial sphere propagation, their self-renewal. Xenotransplantation of immunodeficient recipient mice with a low number of putative CSC allows to determine their tumor initiation ability and their multipotency. While these experimental strategies have obvious limitations and are inherently prone to artifacts, they have been instrumental to elucidate, at least to a certain extent, the complex biology of CSC and their functional implications in a number of tumor types.

Thanks to these research tools, in fact, it has been possible to unravel various signal transduction pathways that play a key role in cancer stemness. These include
Wnt/ß-catenin, NOTCH, IL6/JAK/STAT3, Hedgehog, $\mathrm{NF} K \mathrm{~B}$ and PI3K/AKT, as outlined in recent and exhaustive reviews [40, 41].

Regarding CSC in ovarian carcinoma (OCSC), other pathways have been found in addition to the ones listed above, and implicated in essential stemness-related processes such as self-renewal, tumor initiation and chemoresistance. These include TLR2-MyD88-NFKB [42], HMGA1 [43], PKCi/Ect2/ERK [44], YAP/TEAD [45], hypoxia/NOTCH1/SOX2 [46] and others that, as discussed below, may also represent useful OCSC markers.

\section{Cancer stem cells in ovarian cancer: clinical relevance}

There are many aspects of the biology and clinical evolution of $\mathrm{OC}$ which support the hypothesis that this disease is driven and sustained by CSC. For example, OC is often associated with peritoneal ascites where tumor cell spheroids survive and proliferate even in the absence of adhesion to a substrate. The ability to resist anoikis (the apoptotic program triggered by the loss of anchorage) is a key property of CSC. In fact, the most widely used in vitro assay for cell stemness, namely sphere formation in suspension cultures (Fig. 1), relies on such a property [47]. Accordingly, ascites is enriched in tumor cells with stem-like properties and has been exploited as a rich source of OCSC [48-54].

CSC frequently exhibit a slow cycling rate which makes them inherently resistant to standard chemotherapy and radiotherapy [55-57] that, by definition, target actively proliferating cells. Thus, the high frequency of OC relapse despite optimal cytoreduction and adjuvant chemotherapy might be accounted for by a subpopulation of quiescent OCSC that survive the treatments. These cells would then "wake up" in a later phase, therefore fueling tumor recurrence. Along the same line, the chemoresistance that develops in most relapsed $\mathrm{OC}$, as opposed to the chemosensitivity found in the majority of primary OC, would depend on the higher frequency of CSC. This hypothesis has received support from various studies: Meng et al., for example, reported the correlation between the relative abundance of OC cells with stem-like traits $\left(\mathrm{CD} 44^{+} / \mathrm{CD} 24^{-}\right)$and the higher likelihood of recurrence as well as shorter progression-free survival [58]. Gao et al. screened a series of paired primary, metastatic and recurrent $\mathrm{OC}$ samples for the levels of CD44, a putative CSC marker. A remarkable increase was observed in metastatic and relapsed tumors, toghether with the association with poor outcome. Of note, CD44 was found overexpressed in drug-resistant OC cell lines and up-regulated in mouse models of tumor recurrence following chemotherapy [59]. Similar results were obtained with $\mathrm{CD} 133$, another surface molecule frequently associated with CSC, including OCSC: the expression of CD133, indeed, correlated not only 

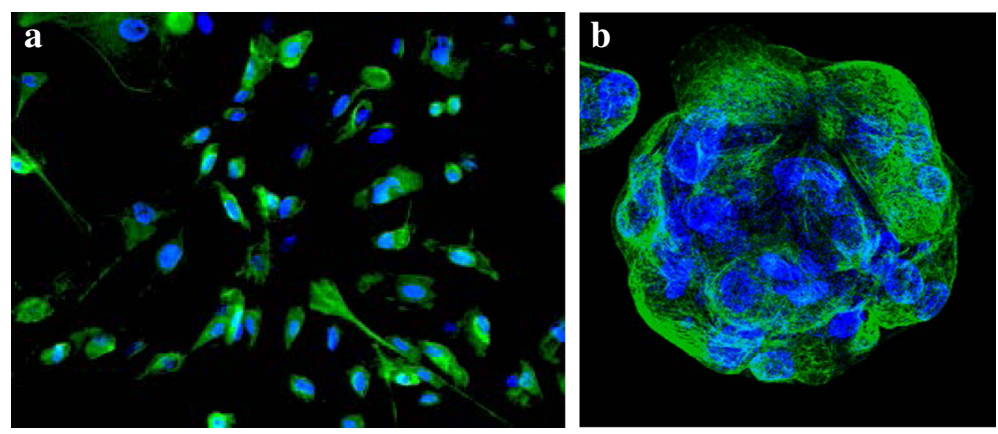

Fig. 1 OC-derived sphere. a Primary tumor cells were isolated from the ascites of a high-grade serous OC, cultured under adherent conditions, and stained for cytokeratin-8 (CK-8, green), a common marker of OC. Original magnification, 10X. b Single cells were then cultured under low-attachment conditions at low cell density and allowed to form clonal spheres. A representative image of a clonal sphere is shown. Sphere-forming cells retained the expression of CK8. Original magnification, 40X

with the clinico-pathological parameters of advanced disease, but also with a decreased response rate to chemotherapy and shorter survival [60]. Other studies which have investigated the prognostic power of different OCSC-related markers, such as ALDH1A1 and CD117, have given similar results [61, 62].

Further evidence in support of the clinical implications of OCSC came from functional genomics studies which, based on their gene expression profiles, identified distinct tumor subtypes enriched in stemness-associated genes and associated with poor prognosis [63, 64]. Moreover, several groups have used individual CSCrelated biomarkers, including surface antigens, enzymes and transcription factors, to interrogate OC cohorts, and in most cases a correlation with clinico-pathological signs of aggressiveness and/or unfavourable outcome could be established [48, 52, 60, 65-73].

\section{Phenotype and biology of OCSC: the markers Surface markers}

A fraction of cells with clonogenic and self-renewing ability was identified in early studies based on semi-solid supports such as soft agar and methylcellulose [74, 75]. However, the first indication of in vivo validated OCSC came from pioneering studies of Bapat and colleagues who identified cell clones with tumorigenic activity from the ascites of a patient with HGSC, and showed that the tumors obtained in xenotransplanted mice recapitulated the histopathological features of the original disease [48]. Thereafter, several reports described the isolation and characterization of OCSC from patient-derived samples, mouse models of OC, or established OC cell lines. Many of those studies relied on the use of surface markers for the purification of OCSC, as outlined below. Table 1 summarizes some of the information on surface proteins proposed as OCSC markers.

CD44 CD44 has been found associated to the sphereforming, self-renewing and tumor-initiating fraction of OC cells in different experimental models. Zhang et al. obtained spheroids from primary $\mathrm{OC}$ cultures and found sphere-derived cells to be tumorigenic at as few as $10^{2}$ cells/mouse, while $10^{5}$ cells were required with the bulk cell population. Spheroids were enriched in CD44expressing cells, and the authors could reproduce the results obtained with sphere-derived cells by simply xenotransplanting 100 cells with the $\mathrm{CD} 44^{+} / \mathrm{CD} 117^{+}$ phenotype [76]. Of note, $\mathrm{CD} 44^{+} / \mathrm{CD} 117^{+}$cells exhibited also higher resistance to chemotherapeutics [77], thus supporting their CSC-like nature. It is interesting that,

Table 1 Cell-surface markers of OCSC

\begin{tabular}{llll}
\hline Marker & Biological function & $\begin{array}{l}\text { Lowest number of } \\
\text { tumorigenic OCSC }\end{array}$ & References \\
\hline CD44 & $\begin{array}{l}\text { HA receptor. Stimulates EGFR-Ras-ERK. Cell proliferation, differentiation, } \\
\text { motility, chemoresistance. }\end{array}$ & $10^{2}\left(\mathrm{CD} 44^{+} /\right.$CD117 $)$ & {$[76-85]$} \\
CD24 & $\begin{array}{l}\text { Transmembrane glycoprotein. Activates STAT3. Stemness, cell adhesion, } \\
\text { tumor cell malignancy, metastasis. }\end{array}$ & $5 \times 10^{3}\left(\mathrm{CD} 24^{+}\right)$ & {$[98-103,105]$} \\
CD117 & $\begin{array}{l}\text { Receptor tyrosine kinase. Regulates PI3K/Akt, Ras/ERK, Src and JAK/STAT } \\
\text { pathways. Cell signaling, apoptosis, cell differentiation, proliferation, } \\
\text { cell adhesion. }\end{array}$ & $10^{3}\left(\mathrm{CD} 117^{+}\right)$ & {$[107-112]$} \\
& $\begin{array}{l}\text { Transmembrane glycoprotein. Induces Pl3K/Akt pathway. } \\
\text { CD133 }\end{array}$ & $10^{2}\left(\mathrm{CD} 133^{+}\right)$ & {$[71,121-124,131-136]$} \\
& CSC maintenance, tumor formation, chemoresistance. & &
\end{tabular}


in addition to its putative role as OCSC biomarker, CD44 seems also to be involved in OCSC pathobiology, as demonstrated by experiments based on its genetic or functional inactivation $[78,79]$. In this context, the molecular mechanisms that underlie the causal role of CD44 in OCSC function could entail its activity as a receptor for hyaluronan (HA), a component of the extracellular matrix. Indeed, the interaction between HA and CD44 triggers a variety of signal transduction pathways. Intriguingly, the binding of HA stimulates the recruitment to CD44 of Nanog, a transcription factor that regulates stemness and chemoresistance in many tumors. The interaction with CD44 induces the activation and the nuclear translocation of Nanog, resulting in the expression of its target genes [80]. The HA-CD44 interaction also promotes the formation of signalling domains at the plasma membrane, which leads to the activation of receptor tyrosine kinase-mediated signalling such as the EGFR-Ras-ERK pathway [81]. This, in turn, may contribute to the proliferation and/or invasiveness of CSC. Finally, CD44 has long been established as a coreceptor for c-Met, the hepatocyte growth factor receptor $[82,83]$. While c-Met has been implicated in CSC from different tumor types [84], no information is available on its role in OCSC. On the other hand, c-Met promotes ovarian cancer progression [85]. On these premises, it is conceivable that the CD44/c-Met signalling unit plays a role in OCSC function, thus representing a potential therapeutic target.

The screening of OC sample cohorts lent further support to the association of CD44 with stemness traits and with the clinical course of the disease. As mentioned above, recurrent OC expressed higher levels of CD44 as compared to matched primary tumors [59], and CD44 levels correlated with poor outcome in several studies [73, 86, 87], including a recent meta-analysis on 957 cases [72]. The latter study, however, reported no association with the response to chemotherapy, which is somehow counterintuitive for a CSC marker. In addition, a number of studies either found no correlation of CD44 with patients' survival $[88,89]$ or even reported CD44 to be associated with better outcome [90-92]. While there might be several reasons that account for such a discrepancy, including different experimental approaches and molecular tools (e.g., CD44 antibodies), different inclusion criteria between the patient cohorts and different degrees of tumor heterogeneity within the individual cohorts, it appears that the clinical value of CD44 as an OCSC biomarker remains controversial. A possible solution would be to focus on alternatively spliced variants of this molecule. Indeed, CD44 exists in various isoforms, depending on ten exons that can be added in different combinations to the standard form of the molecule [93]. While the functional and clinical implications of CD44 variants have been investigated in various tumor types, only limited information is available on their role in CSC [94, 95]. In OC, in particular, CD44v6 was recently shown to be up-regulated in peritoneal metastasis and, more important, a fraction of $\mathrm{CD} 44 \mathrm{v}^{+}$tumor cells displayed metastasis-initiating activity [96], pointing to this variant as a putative marker of OCSC.

CD24 The heat-stable antigen CD24, a glycosylphosphatidylinositol-anchored membrane glycoprotein, has been extensively used as a negative or positive marker of CSC in various cancer types. For example, the low or absent expression of $\mathrm{CD} 24$, in combination with high CD44, marks breast cancer stem cells [97]. Data obtained in various laboratories are consistent with the role of CD24 as a positive marker of CSC in OC. Using a mouse model of OC based on the tissue-specific deletion of Trp53, Pten and Apc, Burgos-Ojeda et al. identified $\mathrm{CD}_{24}{ }^{+}$cells as the tumor-initiating cells. Gao et al. isolated the subset of $\mathrm{CD} 24^{+}$cells from OC specimens and demonstrated that this cell subpopulation displayed higher expression of stemness-associated genes and, more important, was endowed with high tumorinitiating potential [98]. Li et al. supported these observations with experiments on established $\mathrm{OC}$ cell lines, showing not only that the expression of CD24 increased in sphere-forming cells, but also that neutralizing CD24 interferes with their ability to overcome anoikis and generate spheres [99]. Accordingly, tumor cells in OC peritoneal effusions were reported to express higher levels of CD24 than solid tumors, which was proposed as a sign of enrichment in CSC traits [100].

While the functional role of CD24 in OCSC (and in CSC in general) remains poorly defined, recent data have provided novel insights. In particular, CD24 has been shown to enhance the activation of signal transducer and activator of transcription 3 (STAT3) in different tumor types [101-103]. STAT3 activity is a well-established player in cancer stemness and, indeed, CD24-induced STAT3 activation in nasopharyngeal carcinoma cells triggers their reprogramming towards a CSC state [103]. While the causal role of the STAT3 pathway in OCSC has been described [104], its regulation by CD24 remains to be explored. In agreement with the hypothesis of a CD24/STAT3 interplay in ovarian cancer stemness, CD24+ $4^{+}$OCSC exhibit increased levels of STAT3 phosphorylation and of STAT3-dependent expression of stemness factors such as Nanog and c-Myc [105].

It should be mentioned, however, that there are studies which found no evidence for the association of CD24 expression in OC cells with stem cell phenotype or chemoresistance [68]. In fact, other groups including ours 
(Lupia and Cavallaro, unpublished observation) attributed CSC properties to subsets of OC cells with no or low expression of CD24 [58, 106].

CD117 The $c-K I T$ proto-oncogene codes for a receptor tyrosine kinase called CD117, which acts as the receptor for stem cell factor. The role of CD117 as a marker of OCSC has been proposed by several groups. Higher expression of CD117 was described in OC-derived spheres as compared to their adherent counterpart, both in fresh tumor tissue [107] and in OC cell lines [108]. The side population (i.e., a putative stem cell subset; see the section "Side population" below) of a cell line derived from a transgenic mouse model of HGSC was also found enriched in CD117-positive cells, while this was not the case for a cell line established from a mouse model of endometrioid OC [109]. This might imply that different OC subtypes express a different repertoire of surface CSC markers.

Furthermore, as mentioned above, the combined expression of CD117 and CD44 defined a subpopulation of OC cells endowed with tumor-initiating capacity and chemoresistance $[76,77]$. CD117 was also efficient in the isolation of OCSC as a single marker: Luo et al., indeed, showed that the $<2 \%$ fraction of $\mathrm{CD}_{117^{+}}$cells isolated from OC xenografts had a tumorigenic potential 100-fold higher than CD117 cells. Tumors derived from $\mathrm{CD} 117^{+}$cells, in addition, recapitulated the heterogeneity of the original disease and could be serially transplanted, confirming the differentiation and self-renewal abilities of these cells [110]. In other experimental systems, however, CD $117^{+}$ OC cells failed to show increased tumor initiation with respect to CD117 cells [105].

The receptor tyrosine kinase activity of CD117 regulates a wide spectrum of signalling cascades, including PI3K/Akt, Ras/ERK, Src and JAK/STAT [111], all of which are plausible candidates as functional effectors of this surface protein in OCSC. Unfortunately, despite the numerous studies that capitalized on CD117 as an OCSC marker, very little knowledge is available on its biological role in these cells. Functional experiments conducted in two $\mathrm{OC}$ cell lines revealed that both gene silencing and pharmacological inhibition of CD117 kinase activity with imatinib reduced significantly their sphere-forming potential [112], pointing to CD117 as a possible therapeutic target in the context of OCSC. The same study implicated the Wnt/ $\beta$-catenin signalling cascade as an effector of CD117 in the regulation of stemness function [112].

Several multi-kinase inhibitors which have CD117 among their targets have been investigated as therapeutics in ovarian cancer [113-115]. Nevertheless, none of these studies has studied whether such drugs affect the
OCSC subpopulation. Future efforts should be devoted to understanding the biological role of CD117 in OCSC and to testing CD117-targeted compounds as OCSCdirected therapies.

CD133 After the initial characterization as a CSC marker in glioblastoma [116, 117], the surface protein CD133 (also known as prominin-1) was utilized in the identification and/or isolation of CSC in a wide spectrum of solid tumors. However, while harnessing CD133 has allowed significant progress in our understanding of CSC biology, a number of limitations and conflicting data have emerged calling for more caution in the use of CD133 as a widespread CSC marker [118, 119]. OC has not been an exception in this regard. A recent meta-analysis of over 1000 cases has shown a significant correlation between CD133 expression and shorter survival and tumor stage, while no correlation was found with tumor grade or response to therapy [120]. Various groups have detected CD133 in OC-derived subpopulation of cells endowed with properties of tumor initiation, self-renewal and/or chemoresistance [71, 121-124]. Interestingly, the expression of CD133 was silenced by epigenetic mechanisms in the $\mathrm{CD}_{133}{ }^{-}$progeny of $\mathrm{CD}_{133^{+}}$OCSC [125], implicating chromatin modifications in the switch towards a more committed state. Nevertheless, a number of studies did not support the association of CD133 with OCSC. For example, OCSC identified in two cell lines through the expression of ALDH1 (as discussed below) showed inconsistent expression of CD133 [106]. More important, $\mathrm{CD}_{133^{+}}$cells isolated from primary OC cultures failed to prove more spherogenic or tumorigenic than their CD133- counterpart, and in fact they only displayed a slower proliferation rate $[126,127]$. Some of the data published point to the phenotypic heterogeneity and/ or plasticity of OCSC with regard to the expression of CD133 [67, 128], which may, at least in part, account for the controversial findings discussed above. In this context, also the different pattern of immunoreactivity of different anti-CD133 antibodies [129] could underlie discrepancies in the identification of OCSC. The inconsistent data on CD133 as a surface marker in OCSC could also be accounted for by its dynamic subcellular localization, as shown in other tumor types. For example, cytosolic CD133 is a hallmark of highly aggressive gastric cancer [130] and CD133 was found to interconvert between cytosolic and plasma membrane localization in glioblastoma stem cells [131]. Finally, CD133 has been proposed to mark a subset of cells that contribute to OC vascularization, either by entering an endothelial differentiation program [126] or through a paracrine, pro-angiogenic function [132]. 
The functional contribution of CD133 to the pathophysiology of CSC, including OCSC, is poorly defined. Nevertheless, various lines of evidence suggest that CD133 is not only a surface marker but it also plays a causal role in CSC. For example, CD133 is required for the maintenance of glioblastoma stem cells [131] and confers stem-like properties and chemoresistance to other cancer cell types [133-135]. Experimental data implicated the PI3K/Akt pathway as a CD133 effector [133, 134, 136]. Akt pathway inhibitors, are being actively investigated in ovarian cancer therapy [137]. It would be worthwhile, therefore, to study the involvement of Akt downstream of CD133 in ovarian cancer and, in particular, to assess whether targeting Akt signalling affects the self-renewal and tumorigenic potential of CD133positive OCSC.

\section{Functional markers}

The definition of "functional markers" refers to stemness-associated biological activities or functional states that have been exploited for the prospective isolation of OCSC.

ALDH1 Aldehyde dehydrogenases (ALDH) are enzymes that promote the oxidation of aldehyde substrates to their corresponding carboxylic acids. Within the ALDH family, the ALDH1 subgroup is particularly active in normal and cancer stem cells. In particular, among the ALDH1 isozymes (ALDH1A1, ALDH1A2 and ALDH1A3), ALDH1A1 is prominently expressed in CSC. Therefore, ALDH activity and ALDH1A1 expression have been exploited for the identification and purification of CSC across many different cancer types [138]. While the specific role of ALDH1A1 in CSC has not been completely elucidated yet, the protective function of its detoxifying machineries against different insults (preventing for example the accumulation of reactive oxygen species and of reactive aldehydes) is certainly involved in CSC maintenance. In this context, ALDH1 also confers resistance to chemotherapeutics and to radiation [138]. Notably, the widespread use of ALDH1 activity as a CSC marker is largely due to the possibility of determining this activity in live cells and of isolating ALDH1positive cells with a fluorescence-based assay (Aldefluor, StemCell Technologies, Durham, NC, USA). Direct evidence that ALDH1 activity defines a subpopulation of OC cells with CSC-like properties was provided in numerous studies [53, 61, 67, 106, 127, 139]. In particular, a recent report established the superiority of ALDH1 over CD133 in identifying primary OC-derived cells expressing stemness genes and capable of self-renewal and tumor initiation [127]. Along the same line, the ALDH ${ }^{+} / \mathrm{CD} 133^{+}$fraction of OC primary cells was identified at the apex of an OC hierarchy and showed a more multipotent phenotype than all the other marker combinations, including $\mathrm{ALDH}^{-} / \mathrm{CD} 133^{+}$[123]. Data from Condello et al. suggested that ALDH1A1 in OCSC is regulated at the transcriptional level by the $\mathrm{Wnt} / \beta$-catenin pathway, and revealed that a small-molecule ALDH1A1 inhibitor abolished sphere formation, pointing to this enzyme as a potential therapeutic target [140]. Of note, knockdown of the ALDH1A1 gene in OC cell lines restored their sensitivity to chemotherapy both in vitro [141] and in mouse xenograft models [61].

While some of the studies discussed above pointed to the causal role of ALDH1 in conferring CSC traits to OC cells, the underlying molecular mechanism have not been fully elucidated yet. Recent data suggested that ALDH1A1 exerts a regulatory function on the levels of ATP-Binding Cassette $(\mathrm{ABC})$ drug transporters, thus modulating the resistance of $\mathrm{OC}$ cells to chemotherapeutics, although the molecular mechanisms remains to be pinpointed [141]. Interestingly, the role of ALDH1 in OCSC extends beyond its detoxifying activity: Meng et al. showed that the knockdown of ALDH1A1 in the OC cell line A2780 caused a decrease in the cell cycle checkpoints regulators KLF4 and p21 which, in turn, resulted in enhanced cell proliferation [142]. Actively proliferating cells are more susceptible to cytotoxic drugs and, therefore, forcing the cell cycle entry likely contributes to the sensitization of $\mathrm{OC}$ cells to chemotherapy upon loss of ALDH1A1. Furthermore, the ablation of ALDH1A1 triggered DNA damage with a concomitant reduction in various DNA repair pathways [142], implying that ALDH1A1 exerts a genome-protecting role in OCSC. The anti-proliferative role of ALDH1A1 reported by Meng et al. was contradicted by data obtained in primary OC-derived cells where the genetic or pharmacological inactivation resulted in decreased proliferation [127]. In this experimental system, the authors also identified an intriguing interplay between ALDH1A1 and the stemness-associated gene SOX2 and showed that their reciprocal regulation orchestrates sphere formation and OCSC survival and proliferation [127].

Side population Besides ALDH1 activity, the functional feature that has been most extensively used for the isolation of OCSC is the ability to efflux the lipophilic dye Hoechst 33342 due to the selective expression of $A B C$ transporters. Cells endowed with such a property are called side-population (SP) cells due to their position in FACS panels [143]. In OC, this method was first applied to the identification of tumor-initiating cells from the transgenic mouse model of OC known as MISIIR-TAg [109]. Thereafter, increased expression of stemnessrelated genes and tumorigenic capacity were reported in SP cells isolated from a panel of OC cell lines as well as from human tumors [144, 145]. Of note, the SP fraction 
purified from different $\mathrm{OC}$ cell lines was highly heterogeneous with regard to the expression of other markers [146], raising the question of whether cells with multiple phenotypes can co-exist in the CSC compartment or one single subset contained in SP cells represents bona fide OCSC.

Label retention In various tumor types, CSC are thought to be mostly quiescent or at least to have a very slow cycling rate. This property has been harnessed by a number of laboratories to isolate quiescent CSC from the bulk of actively proliferating tumor cells. In particular, this type of technology is based on the principle, schematically depicted in Fig. 2, that, upon labelling a cell population with a fluorescent vital dye, the latter will be progressively diluted in dividing cells while quiescent cells will retain it and can be purified by FACS-based strategies. For example, retention of the lipophilic dyes of the PKH class (which intercalate in the cell membranes) was used for the isolation of quiescent OCSC and allowed to demonstrate the reversibility of their state to an active proliferating phenotype when their clonogenic or tumorigenic function is stimulated [147]. Recently, by applying the $\mathrm{PKH}$ technology to an in vivo model of OC, Bapat et al. identified gene modules specifically associated to the individual tumor cell fractions separated on the basis of their PKH retention, and defined CD53 as a novel marker of OC-initiating cells within the $\mathrm{PKH}^{\text {high }}$ subset [148]. PKH retention was also used as a proof of quiescence during the characterization of polyploid giant cancer cells as OCSC [149].

The isolation of label-retaining OCSC entails, by definition, the manipulation of the system (e.g., biochemical or genetic labelling, expansion of tumor cells to allow for label dilution, etc.), which obviously increases the risk of artifacts. In addition, label retention marks quiescent cells which, however, not necessarily coincide with CSC. These limitations should be taken into account when applying label retention-based strategies. Yet, the latter offer the possibility to discover molecular and

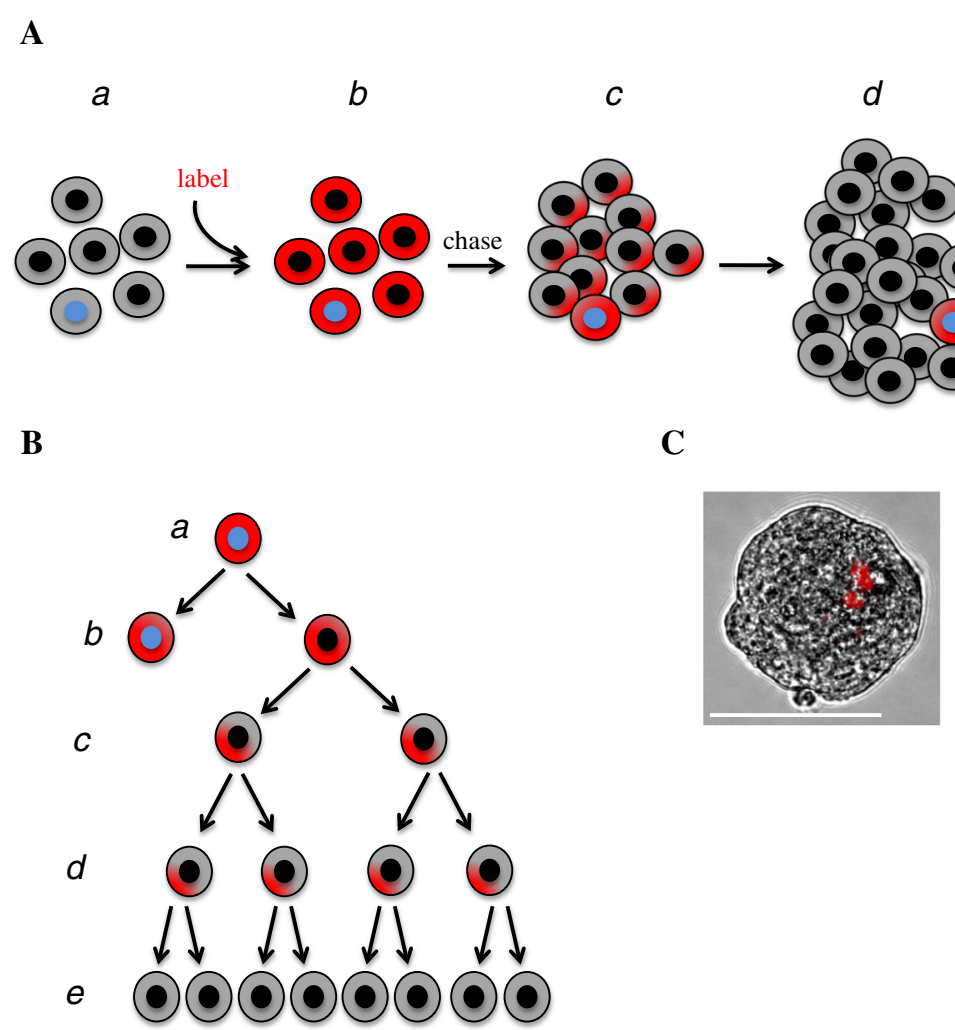

Fig. 2 Label retention in CSC. (A) Schematic representation of label retention. A bulk population of tumor cells (a) is labeled with a vital dye so that all cells become labeled (b). During the following chase period, actively dividing cells (black nuclei) progressively lose the dye by diluting it to daughter cells $(c, d)$. In contrast, CSC (blue nucleus), due to their slow cycling rate, retain the dye much longer and can thus be identified (d). (B) Label retention during sphere formation. When labeled, single CSC (a) are cultured under low-attachment conditions they undergo asymmetric division to generate another CSC and a progenitor cell (b). While the daughter CSC enters quiescence thus retaining the dye (b), the progenitor give rise to a progeny of proliferating cells (c), which form the bulk of sphere cells, in which the dye is progressively lost $(d, e)$. The final result, as shown in (C), is a clonal sphere with only one or very few label-retaining CSC. The image shows a sphere from primary OC cells labeled with PKH26. Scale bar, $100 \mu \mathrm{m}$ 
biological features of CSC, provided that the findings are validated in clinically relevant systems. For example, the transcriptomic profile of $\mathrm{PKH}$-retaining mammary cells has yielded a panel of differentially expressed genes that have then been proven useful for the prospective identification of CSC from breast tumor tissue [150]. Quiescent CSC can also be tracked genetically, for example through the retention of green fluorescent proteintagged histone 2B (H2B-GFP). This approach can be combined with animal models of spontaneous tumorigenesis, thus making it possible to identify label-retaining CSC in preclinical tumor models that recapitulate, at least to some extent, the natural history of the disease. Longterm retention of H2B-GFP favoured the identification and characterization of stem cells in the ovarian and oviductal epithelium of transgenic mice [151, 152]. Applying this strategy to mouse models of spontaneous ovarian carcinogenesis should help defining novel molecular and functional features of OCSC, not only in the context of tumor initiation, but also in dissemination, recurrence and chemoresistance.

It should not be neglected, however, that PKHretaining cells isolated from $\mathrm{OC}$ specimens failed to show higher tumorigenic potential when compared to their PKH-negative counterparts and, in fact, exhibited lower clonogenic activity in vitro and longer tumor latency in xenograft models [153]. Results in our laboratory with either PKH or H2B-GFP indicated that label retention in primary $\mathrm{OC}$ cells does not mark cells with specific OCSC-like traits (Lupia and Cavallaro, unpublished data). These observations might imply that $\mathrm{OC}$ is highly heterogeneous with regard to the quiescent nature of its CSC compartment, and that slow cycling is not an absolute and universal feature of OCSC.

\section{The normal counterpart of OCSC}

The origin of CSC remains a highly debated and controversial issue. Based on the functional and phenotypic similarities between CSC and normal tissue stem cells (self-renewal, differentiation, quiescence, shared markers, etc.), CSC were initially proposed to derive from normal SC that have undergone malignant transformation. More recent evidence, however, pointed to the dedifferentiation and reprogramming of "mature" tumor cells as an additional mechanism to generate bona fide CSC. Furthermore, it has been proposed that tumor cells convert dynamically between stem and nonstem states, a plasticity that can be orchestrated by microenvironmental cues [38]. These models are not mutually exclusive, and it is likely that different pathways underlie the origin of CSC in different tumor types. In addition, different mechanisms may occur within the same tumor [38], possibly accounting for the generation of distinct CSC subsets. The intra- tumor heterogeneity of CSC, indeed, has been reported in certain cancer types, one of the best examples being ovarian cancer $[146,154]$.

Regardless whether CSC originate from normal stem cells (SC) of the same tissue, investigating the latter has provided significant insights into the biological features of CSC. For example, certain signalling pathways governing the stem phenotype in CSC have been identified also in normal SC, and in some cases signature inferred from normal SC have been used to prospectively identify the CSC in the corresponding tumor tissue [30, 150]. In addition, comparing normal SC with CSC might help to identify molecular drivers that act specifically in CSC, possibly resulting in a better understanding of CSC biology and in CSC-targeted therapies.

In the context of $\mathrm{OC}$, this approach must face both biological and methodological challenges mainly linked to the tissue of origin and, therefore, to the somatic SC that one should consider as the normal counterpart of OCSC.

$\mathrm{OC}$ has long been thought to derive from the neoplastic transformation of cells belonging to the ovarian surface epithelium (OSE), a monolayer of cells with mesothelial characteristics lining the ovary $[13,14]$. Recent clinical and experimental data, however, have demonstrated that a significant fraction of $\mathrm{OC}$ originate in non-ovarian tissues [155]. This is best exemplified by HGSC, for which the precursor lesion is often localized within the distal fallopian tube epithelium (FTE), and is driven by TP53-mutated FTE cells [17, 18]. A recent phylogenetic analysis of the tumor mutational profile has confirmed the frequent tubal histogenesis of HGSC, although in some cases the FT itself appeared to be a metastatic site [156].

From a methodological standpoint, the poor accessibility and the difficult handling of OSE and FTE have posed major obstacles to the identification and characterization of SC residing in these tissues. Nevertheless, as discussed below, a few studies have addressed this question and provided intriguing information.

\section{OSE stem cells}

Tracing quiescent cells through their long-term retention of 5-bromo-2-deoxyuridine (BrdU) and H2B-GFP has revealed a subset of SC-like cells in OSE of adult mice which displayed asymmetric cell division and higher clonogenic potential when compared to their non label-retaining counterpart [151]. The SP analysis (described above) was instead employed by Gamwell et al. [157] to isolate rare SC from mouse OSE which expressed the classical SC marker Ly6A/Sca-1 and had higher sphere-forming efficiency. These studies, however, did not explore the possible relation of OSEderived SC with OCSC. Such a question, instead, was 
address by the researchers who identified a SC subpopulation in the ovary hilum, which is a transitional area between the OSE, mesothelium and the oviduct. Besides exhibiting a wide spectrum of phenotypical and functional features classically associated with stemness, hilum-derived SC were more susceptible to the neoplastic transformation induced by the deletion of Trp53 and $R b 1$, implying that the ovary hilum may act as the niche for OCSC [158]. This study showed that OSE-derived SC express the surface protein Lgr5, previously characterized as a SC marker in different epithelia [158]. Subsequent in vivo tracing identified $\mathrm{Lgr}^{+} \mathrm{SC}$ not only in the hilum but also in other regions of the OSE and in the tubal epithelium [159]. Of note, this paper documented the role of $\operatorname{Lgr}^{+}$cells in OSE homeostasis and in epithelial regeneration following ovulation-induced damage, providing compelling evidence of their SC nature [159].

\section{FTE stem cells}

In addition to $\mathrm{Ng}$ et al. [159], a few other studies have addressed the identification of $\mathrm{SC}$ in the fallopian tube. Pulse-chase experiments in mice expressing H2B-GFP in an inducible fashion revealed the presence of long-term, label-retaining (i.e., quiescent) cells in the distal portion of mouse oviduct. These cells were capable of sphere formation of differentiation towards different lineages of the female reproductive system [152]. Label-retaining cells in mouse oviduct were also identified through pulse-chase experiments with $\mathrm{BrdU}$, although their SC nature was not further investigated [160]. Paik et al. [161] identified a subpopulation of basally located cells that do not express the typical markers of ciliated or secretory cells, the two cell lineages that compose the FTE, while expressing CD44. These cells, termed FTESC and found to correspond to the so-called peg cells, were enriched for sphere-forming activity. Notably, an expansion of FTESC was found both in HGSC lesions and in the normal appearing FTE adjacent to HGSC sites [161], possibly implicating FTESC in the pathogenesis of this cancer type. Direct functional evidence in support of the causal link between human FTE-derived SC and OC development was provided by the in vitro immortalization with $h T E R T$ and transformation with $c-M Y C$, an oncogene that is frequently overexpressed in OC. Besides having tumor-initiating potential, these transformed FTE-derived SC upon xenotransplantation into immunodeficient mice generated tumors that recapitulated both the histopathological and transcriptomic features of HGSC [162]. Finally, the stemness-related gene SOX2, which appears to be causally involved in OC stemness [163], was found to be expressed only in rare FTE cells in women with benign conditions, while SOX2-expressing cells were expanded in the FTE of patients affected by HGSC [164]. Moreover, higher frequency of SOX2expressing cells was detected also in the fallopian tubes of women that were at high risk of developing ovarian cancer because of germline BRCA1/2 mutations [164], thus lending further support to the hypothesis that FTE is a prominent site of precursor lesions of HGSC.

\section{Final remarks on OCSC markers}

Based on the studies discussed above, it is striking to see how heterogeneous are the sets of putative OCSC markers used by different groups, especially if compared with other tumor types where there is a more general consensus on the CSC-associated repertoire of surface antigens (e.g., CD $44^{+} / \mathrm{CD} 24^{-}$in breast carcinoma, LGR5 ${ }^{+}$ in colon carcinoma, $\mathrm{CD} 133^{+}$in glioblastoma). The variegated picture in OCSC markers is likely due to a combination of different factors. First, the heterogeneity of the disease itself, which encompasses the different histotypes (likely reflecting different tissues of origin and tumor precursors) as well as the molecular alterations, with only a handful of genomic lesions shared by tumors of the same group (e.g. p53 in HGSC) and, otherwise, a very heterogeneous mutational landscape. Second, different sets of OCSC markers might simply reflect the existence of different pools of OCSC. In fact, the heterogeneity of CSC is common across various tumor types [38], which apparently include OC. Indeed, Boesch et al. screened several $\mathrm{OC}$ cell lines and found that their SP compartment, while enriched in CSC functional properties, contained different cell subsets with distinct surface markers [146]. It is conceivable, therefore, that cell pools with different phenotypical (and maybe biological) properties share stemness and tumorpropagating abilities. On the other hand, these findings are also compatible with a pronounced plasticity of OCSC, whereby the expression of different markers underlies different phases of the disease or different states of cell differentiation. The two phenomena would not be mutually exclusive, implying that the heterogeneity of OCSC might result from both distinct subsets of cells and cell plasticity.

Furthermore, while one would expect OCSC to represent a minor subpopulation of cancer cells, the prevalence of cells expressing putative CSC markers, such as CD44 and CD24, is often high in OC specimens. On one hand, this might reflect a massive shift of the bulk tumor cell population towards an undifferentiated phenotype (which indeed can be the case in some HGSC and carcinosarcoma). On the other hand, it is highly unlikely that all marker-positive cells identified through these markers are actually bona fide CSC. Rather, CSC would probably account only for subsets of that population, which implies the need to employ more stringent marker 
combinations and/or to associate marker expression with other biological CSC features.

\section{The stem cell niche: a specialized microenvironment}

The acquisition and the maintenance of the biological properties associated with stemness are driven, both in normal and neoplastic tissues, by the interplay between cell-intrinsic characteristics and the interaction with the local microenvironment. Such a microenvironment often consists of a distinct anatomical site within the tumor mass, the so-called stem cell niche. It has become clear that all niche components, i.e. non-stem cancer cells, other host cells, extracellular matrix and soluble factors, regulate various aspects of stem cell biology, including quiescence, mode of division (symmetric versus asymmetric), differentiation, EMT and plasticity. The biological, molecular and functional features of the CSC niche, as well its clinical implications, have been comprehensively discussed in recent reviews $[38,165,166]$.

\section{The normal SC niche}

With regard to the ovary, the nature and the properties of the niche for either normal SC or CSC have remained largely elusive. In the case of normal OSE and FTE, the two major sources of OC, our poor knowledge on somatic SC niches is likely a consequence of the issues and controversies related to the identification of the SC themselves (see section on "The normal counterpart of OCSC").

OSE niche As reported earlier, Flesken-Nikitin and coworkers identified putative OSE SC in the hilum region of mouse ovary, namely in the junctional area between OSE, mesothelium and fallopian tube [158]. While these observations point to that anatomical site as a plausible $\mathrm{SC}$ niche, the components of the niche itself and their regulatory role in OSE SC function remain to be defined. Furthermore, it is unclear to what extent this niching effect of the mouse hilum also extends to the human system, where areas of transition between OSE, mesothelium and tubal epithelium are less defined. It is also noteworthy that other investigators detected somatic SC in the OSE which, however, were widespread throughout the surface rather than restricted to specific areas [151, 159]. Consistent with this pattern, various components of the ovarian cortex have been proposed to have a SC niching function, including mature OSE cells, follicles, follicular fluid, and the stroma underneath the OSE [167].

FTE niche The SC niche in the fallopian tube remains an elusive entity. As reported earlier, a few studies have identified somatic SC in the distal portion of FTE [152, 159-161]. In some cases, the localization of SC at the base of tubal villi [160] pointed to a specialized microenvironment which, however, has not been characterized yet. Based on the physical proximity of the distal fallopian tube with the ovary, it is conceivable that SC in FTE and in OSE share at least some of the niche components and signals [167]. Novel insights into these issues should come from the organoid culture, a methodology that recapitulates SC-driven morphogenesis in vitro [168]. Indeed, the recent application of this technique to primary FTE cells has revealed the major role of the Notch and Wnt signalling pathways as niche factors that regulate stemness and differentiation [169]. Future studies should aim at assessing the relative contributions of other components of the niche (e.g., non-epithelial cells) to the function of normal SC in FTE and OSE.

\section{The OCSC niche}

OCSC niche in solid tumors The characterization of the niche(s) that supports OCSC must take into account the clinical course of the disease. One can expect that in OC lesions still localized within the ovary and/or the tube, the CSC compartment benefits from the same niche that operates for the normal somatic SC of those tissues (in addition, of course, to the niche factors derived from the tumor itself). On the other hand, the natural evolution of the disease, and especially its peritoneal dissemination, implies the existence of multiple types of niches that support the pathobiological function of OCSC in different anatomical districts. The high rate of OC relapse in peritoneal organs implies that the latter provide a microenvironment which not only protects quiescent disseminated OCSC in the presence of unfavourable conditions (such as during chemotherapy), but also sustains their tumorigenic activity in the context of OC recurrence. These events are very likely controlled by the bidirectional exchange of signalling cues between niche cells and OCSC. For example, organotypic 3D cultures that recapitulated the early dissemination of $\mathrm{OC}$ into peritoneal mesothelium revealed that cancer cells, via secretion of transforming growth factor beta-1 (TGF $\beta 1$ ), induce mesothelial cells to synthesize fibronectin [170]. The latter is essential for the adhesion, proliferation and invasion of $\mathrm{OC}$ cells and, hence, for metastasis development [170]. More recently, OCderived exosomes were reported to transfer CD44 into mesothelial cells, resulting in upregulation of matrix metalloproteinase 9 (MMP9) that, in turn, favoured cancer cell homing and invasion. The adipose tissue, especially within the omentum, also provides an optimal environment for the formation of OC lesions. Coculture experiments have shown that omental adipocytes enhance homing, migration and invasion of $\mathrm{OC}$ cells and act as an energy source to sustain their metastatic potential 
[171]. While these studies have not directly addressed the specific impact of microenvironmental factors on OCSC, they highlighted suitable approaches and tools to explore the cellular and molecular players involved in the crosstalk between OCSC and their niche.

OCSC niche in ascites The ascites that develops in advanced $\mathrm{OC}$, both at diagnosis and upon recurrence and development of chemoresistance [172], represents a unique type of tumor microenvironment. Indeed, ascites contains malignant cells which are able to survive and to proliferate even under non-adherent conditions, leading to self-organized spheroids of OC cells that, in turn, account for peritoneal seeding. In addition, ascites contains a wide spectrum of cellular and acellular components that provide a unique microenvironment to malignant $\mathrm{OC}$ cells [173]. Several studies have reported that ascites is a rich source of cells with OCSC traits [50-52, 54, 145, 174]. Based on these premises, ascites can be viewed as a specialized OCSC niche, and future research should unravel the ascitic factors that are specifically involved in the regulation of OCSC. For example, interleukin-6 (IL-6) is elevated in ascites [175-179]. IL-6 triggers the JAK/STAT3 signalling pathway [180], which plays an important role in OCSC function [104]. Finally, ascites-derived OC cells display high levels of STAT3 activation [181]. Taken together, these findings suggest that the IL-6/JAK/STAT3 axis is an important effector of the "communication" between OCSC and their niche within the ascites microenvironment. The Wnt signalling pathway likely represents another candidate for such a communication, based on the enrichment for Wnt ligands in OC ascites [182, 183], the activation of Wnt pathway in ascites-derived OCSC [184], and the functional contribution of Wnt signalling to OC stemness $[185,186]$.

These results have relevant implications also from a clinical standpoint, since drugs targeting STAT3 and Wnt pathways appear particularly effective against ascitesderived malignant OC cells $[187,188]$.

\section{Conclusions and future perspectives}

In spite of the challenges and limitations related to the intrinsic complexity of $\mathrm{OC}$ itself and of its current experimental models, there is no doubt that our knowledge on such an elusive biological entity as OCSC has made tremendous progress over the last few years. The clinical utility of this knowledge, which has started to emerge at least in the context of prognosis and prediction of response to chemotherapy, will hopefully become clearer when translated into novel therapeutic approaches. However, the future research effort towards such a challenging objective will have to take into account, in primis, the heterogeneity of OC. One can envision that, in view of OCSC-based precision medicine, it will be necessary to develop appropriate OCSC models that are specific not only for a given $\mathrm{OC}$ variant, but even for the individual patient. Along the same line, an appropriate design of clinical trials addressing OCSC-related questions should incorporate the high heterogeneity of the disease with regard to OCSC markers (even the most common markers are found in only $<40 \%$ tumors), which would impose a careful selection of the right patient cohorts. In addition, monitoring OCSC in the course of clinical trials should entail longitudinal biopsies, while most translational studies in OC focus on the primary tumor. Indeed, OCSC are supposed to account for a very small subpopulation in the primary tumor but should enrich in recurrent disease, both because of their expansion to fuel the relapse and because of the possible selection of drug-resistant OCSC after the first-line treatment.

The successful elimination of OCSC would have tremendous implications for the clinical management of patients. Indeed, it would offer the unprecedented chance of targeting the driving force of disease dissemination and recurrence while, at the same time, removing the major cause of tumor resistance to conventional chemotherapy. This makes the combination of classical treatments and OCSC-based therapies a very attractive and promising strategy towards the eradication of $\mathrm{OC}$, with the potential to impact significantly the outcome of OC patients, an objective that we basically failed to accomplish in the last 40 years.

\section{Acknowledgement \\ We apologize to all those colleagues whose important work could not be discussed due to space limitations. Michela Lupia was supported by a fellowship from Fondazione Istituto Europeo di Oncologia. \\ Funding \\ The work in the authors' laboratory was supported by Associazione Italiana Ricerca sul Cancro (AIRC), Worldwide Cancer Research (formerly known as Association for International Cancer Research), the Fondazione Istituto Europeo di Oncologia, the Italian Ministry of Health, and Cariplo Foundation.}

Availability of data and materials Not applicable.

\section{Authors' contributions}

$\mathrm{ML}$ contributed to the manuscript and generated the results shown in the figures. UC wrote the manuscript and prepared the figures. Both authors read and approved the final manuscript.

\section{Competing interests}

The authors declare that they have no competing interests.

Consent for publication

Not applicable.

Ethics approval and consent to participate Not applicable.

\section{Publisher's Note}

Springer Nature remains neutral with regard to jurisdictional claims in published maps and institutional affiliations. 
Received: 13 December 2016 Accepted: 13 March 2017 Published online: 20 March 2017

\section{References}

1. Webb PM, Jordan SJ. Epidemiology of epithelial ovarian cancer. Best Pract Res Clin Obstet Gynaecol. 2016. doi:10.1016/j.bpobgyn.2016.08.006.

2. Siegel RL, Miller KD, Jemal A. Cancer statistics, 2016. CA Cancer J Clin. 2016; 66:7-30.

3. Matulonis UA, Sood AK, Fallowfield L, Howitt BE, Sehouli J, Karlan BY. Ovarian cancer. Nat Rev Dis Primers. 2016;2:16061.

4. Chang SJ, Hodeib M, Chang J, Bristow RE. Survival impact of complete cytoreduction to no gross residual disease for advanced-stage ovarian cancer: a meta-analysis. Gynecol Oncol. 2013:130:493-8.

5. Kurman RJ, Shih IM. The origin and pathogenesis of epithelial ovarian cancer: a proposed unifying theory. Am J Surg Pathol. 2010;34:433-43.

6. Kurman RJ, Shih IM. The Dualistic Model of Ovarian Carcinogenesis: Revisited, Revised, and Expanded. Am J Pathol. 2016;186:733-47.

7. Bowtell DD, Bohm S, Ahmed AA, Aspuria PJ, Bast Jr RC, Beral V, Berek JS, Birrer MJ, Blagden S, Bookman MA, Brenton JD, Chiappinelli KB, Martins FC, Coukos G, Drapkin R, Edmondson R, Fotopoulou C, Gabra H, Galon J, Gourley C, Heong V, Huntsman DG, Iwanicki M, Karlan BY, Kaye A, Lengyel E, Levine DA, Lu KH, McNeish IA, Menon U, Narod SA, Nelson BH, Nephew KP, Pharoah P, Powell Jr DJ, Ramos P, Romero IL, Scott CL, Sood AK, Stronach EA, Balkwill FR. Rethinking ovarian cancer Il: reducing mortality from highgrade serous ovarian cancer. Nat Rev Cancer. 2015;15:668-79.

8. Choi HJ, Armaiz Pena GN, Pradeep S, Cho MS, Coleman RL, Sood AK. Antivascular therapies in ovarian cancer: moving beyond anti-VEGF approaches. Cancer Metastasis Rev. 2015;34:19-40.

9. Ledermann JA, Embleton AC, Raja F, Perren TJ, Jayson GC, Rustin GJ, Kaye SB, Hirte H, Eisenhauer E, Vaughan M, Friedlander M, Gonzalez-Martin A, Stark D, Clark E, Farrelly L, Swart AM, Cook A, Kaplan RS, Parmar MK. Cediranib in patients with relapsed platinum-sensitive ovarian cancer (ICON6): a randomised, double-blind, placebo-controlled phase 3 trial. Lancet. 2016;387:1066-74.

10. Konecny GE, Kristeleit RS. PARP inhibitors for BRCA1/2-mutated and sporadic ovarian cancer: current practice and future directions. Br J Cancer. 2016:115:1157-73.

11. Ledermann JA, Drew Y, Kristeleit RS. Homologous recombination deficiency and ovarian cancer. Eur J Cancer. 2016;60:49-58.

12. Gaillard SL, Secord AA, Monk B. The role of immune checkpoint inhibition in the treatment of ovarian cancer. Gynecol Oncol Res Pract. 2016;3:11.

13. Fathalla MF. Incessant ovulation-a factor in ovarian neoplasia? Lancet. 1971; 2:163.

14. Auersperg N, Wong AS, Choi KC, Kang SK, Leung PC. Ovarian surface epithelium: biology, endocrinology, and pathology. Endocr Rev. 2001;22: 255-88.

15. Dubeau L, Drapkin R. Coming into focus: the nonovarian origins of ovarian cancer. Ann Oncol. 2013;24 Suppl 8:viii28-35.

16. Fathalla MF. Incessant ovulation and ovarian cancer - a hypothesis re-visited. Facts Views Vis Obgyn. 2013:5:292-7.

17. George SH, Garcia R, Slomovitz BM. Ovarian Cancer: The Fallopian Tube as the Site of Origin and Opportunities for Prevention. Front Oncol. 2016;6:108.

18. Perets R, Drapkin R. It's Totally Tubular...Riding The New Wave of Ovarian Cancer Research. Cancer Res. 2016;76:10-7.

19. Meserve EE, Brouwer J, Crum CP. Serous tubal intraepithelial neoplasia: the concept and its application. Mod Pathol. 2017. doi:10.1038/modpathol.2016. 238.

20. TCGA. Integrated genomic analyses of ovarian carcinoma. Nature. 2011;474: 609-15.

21. Patch AM, Christie EL, Etemadmoghadam D, Garsed DW, George J, Fereday S, Nones K, Cowin P, Alsop K, Bailey PJ, Kassahn KS, Newell F, Quinn MC Kazakoff S, Quek K, Wilhelm-Benartzi C, Curry E, Leong HS, Hamilton A Mileshkin L, Au-Yeung G, Kennedy C, Hung J, Chiew YE, Harnett P, Friedlander M, Quinn M, Pyman J, Cordner S, O'Brien P, Leditschke J, Young G, Strachan K, Waring P, Azar W, Mitchell C, Traficante N, Hendley J, Thorne H, Shackleton M, Miller DK, Arnau GM, Tothill RW, Holloway TP, Semple T, Harliwong I, Nourse C, Nourbakhsh E, Manning S, Idrisoglu S, Bruxner TJ, Christ AN, Poudel B, Holmes O, Anderson M, Leonard C, Lonie A, Hall N, Wood S, Taylor DF, Xu Q, Fink JL, Waddell N, Drapkin R, Stronach E, Gabra H, Brown R, Jewell A, Nagaraj SH, Markham E, Wilson PJ, Ellul J, McNally O, Doyle MA, Vedururu R, Stewart C, Lengyel E, Pearson JV, Waddell N, de
Fazio A, Grimmond SM, Bowtell DD. Whole-genome characterization of chemoresistant ovarian cancer. Nature. 2015:521:489-94.

22. Hasan N, Ohman AW, Dinulescu DM. The promise and challenge of ovarian cancer models. Transl Cancer Res. 2015:4:14-28.

23. Domcke S, Sinha R, Levine DA, Sander C, Schultz N. Evaluating cell lines as tumour models by comparison of genomic profiles. Nat Commun. 2013:4:2126.

24. Anglesio MS, Wiegand KC, Melnyk N, Chow C, Salamanca C, Prentice LM, Senz J, Yang W, Spillman MA, Cochrane DR, Shumansky K, Shah SP, Kalloger SE, Huntsman DG. Type-specific cell line models for type-specific ovarian cancer research. PLoS One. 2013;8:e72162

25. Beaufort CM, Helmijr JC, Piskorz AM, Hoogstraat M, Ruigrok-Ritstier K, Besselink N, Murtaza M, van IJcken WF, Heine AA, Smid M, Koudijs MJ, Brenton JD, Berns EM, Helleman J. Ovarian cancer cell line panel (OCCP): clinical importance of in vitro morphological subtypes. PLoS One. 2014;9: e103988.

26. Sinha R, Schultz N, Sander C. Comparing cancer cell lines and tumor samples by genomic profiles. bioRxiv. 2015. https://doi.org/10.1101/028159.

27. Elias KM, Emori MM, Papp E, MacDuffie E, Konecny GE, Velculescu VE, Drapkin R. Beyond genomics: critical evaluation of cell line utility for ovarian cancer research. Gynecol Oncol. 2015;139:97-103.

28. Kreso A, Dick JE. Evolution of the cancer stem cell model. Cell Stem Cell. 2014;14:275-91.

29. Visvader JE. Cells of origin in cancer. Nature. 2011:469:314-22.

30. Dzobo K, Senthebane DA, Rowe A, Thomford NE, Mwapagha LM, Al-Awwad N, Dandara C, Parker MI. Cancer Stem Cell Hypothesis for Therapeutic Innovation in Clinical Oncology? Taking the Root Out. Not Chopping the Leaf Omics. 2016;20:681-91.

31. Thiery JP, Acloque H, Huang RY, Nieto MA. Epithelial-mesenchymal transitions in development and disease. Cell. 2009;139:871-90.

32. Iwatsuki M, Mimori K, Yokobori T, Ishi H, Beppu T, Nakamori S, Baba H, Mori M. Epithelial-mesenchymal transition in cancer development and its clinical significance. Cancer Sci. 2010;101:293-9.

33. Pradella D, Naro C, Sette C, Ghigna C. EMT and stemness: flexible processes tuned by alternative splicing in development and cancer progression. Mol Cancer. 2017;16:8

34. Ahmed N, Abubaker K, Findlay J, Quinn M. Epithelial mesenchymal transition and cancer stem cell-like phenotypes facilitate chemoresistance in recurrent ovarian cancer. Curr Cancer Drug Targets. 2010;10:268-78.

35. Mani SA, Guo W, Liao MJ, Eaton EN, Ayyanan A, Zhou AY, Brooks M, Reinhard F, Zhang CC, Shipitsin M, Campbell LL, Polyak K, Brisken C, Yang J, Weinberg RA. The epithelial-mesenchymal transition generates cells with properties of stem cells. Cell. 2008;133:704-15.

36. Nieto MA, Huang RY, Jackson RA, Thiery JP. EMT: 2016. Cell. 2016;166:21-45.

37. Chaffer CL, San Juan BP, Lim E, Weinberg RA. EMT, cell plasticity and metastasis. Cancer Metastasis Rev. 2016;35:645-54.

38. Boesch M, Sopper S, Zeimet AG, Reimer D, Gastl G, Ludewig B, Wolf D. Heterogeneity of Cancer Stem Cells: Rationale for Targeting the Stem Cell Niche. Biochim Biophys Acta. 1866;2016:276-89.

39. Orecchioni S, Bertolini F. Characterization of Cancer Stem Cells. Methods Mol Biol. 2016;1464:49-62.

40. labal W, Alkarim S, AlHejin A, Mukhtar H, Saini KS. Targeting signal transduction pathways of cancer stem cells for therapeutic opportunities of metastasis. Oncotarget. 2016;7:76337-53.

41. Matsui WH. Cancer stem cell signaling pathways. Medicine (Baltimore). 2016 95:S8-s19.

42. Chefetz I, Alvero AB, Holmberg JC, Lebowitz N, Craveiro V, Yang-Hartwich Y, Yin G, Squillace L, Gurrea Soteras M, Aldo P, Mor G. TLR2 enhances ovarian cancer stem cell self-renewal and promotes tumor repair and recurrence. Cell Cycle. 2013;12:511-21.

43. Kim DK, Seo EJ, Choi EJ, Lee SI, Kwon YW, Jang IH, Kim SC, Kim KH, Suh DS, Seong-Jang K, Lee SC, Kim JH. Crucial role of HMGA1 in the self-renewal and drug resistance of ovarian cancer stem cells. Exp Mol Med. 2016;48:e255.

44. Wang Y, Hill KS, Fields AP. PKCiota maintains a tumor-initiating cell phenotype that is required for ovarian tumorigenesis. Mol Cancer Res. 2013; 11:1624-35

45. Xia Y, Zhang YL, Yu C, Chang T, Fan HY. YAP/TEAD co-activator regulated pluripotency and chemoresistance in ovarian cancer initiated cells. PLoS One. 2014:9:e109575

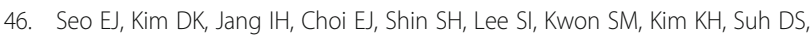
Kim JH. Hypoxia-NOTCH1-SOX2 signaling is important for maintaining cancer stem cells in ovarian cancer. Oncotarget. 2016;7:55624-38. 
47. Dontu G, Abdallah WM, Foley JM, Jackson KW, Clarke MF, Kawamura MJ, Wicha MS. In vitro propagation and transcriptional profiling of human mammary stem/progenitor cells. Genes Dev. 2003;17:1253-70.

48. Bapat SA, Mali AM, Koppikar CB, Kurrey NK. Stem and progenitor-like cells contribute to the aggressive behavior of human epithelial ovarian cancer. Cancer Res. 2005;65:3025-9.

49. Ho CM, Chang SF, Hsiao CC, Chien TY, Shih DT. Isolation and characterization of stromal progenitor cells from ascites of patients with epithelial ovarian adenocarcinoma. J Biomed Sci. 2012;19:23.

50. Wintzell M, Hjerpe E, Avall Lundqvist E, Shoshan M. Protein markers of cancer-associated fibroblasts and tumor-initiating cells reveal subpopulations in freshly isolated ovarian cancer ascites. BMC Cancer. 2012;12:359.

51. Latifi A, Luwor RB, Bilandzic M, Nazaretian S, Stenvers K, Pyman J, Zhu H, Thompson EW, Quinn MA, Findlay JK, Ahmed N. Isolation and characterization of tumor cells from the ascites of ovarian cancer patients: molecular phenotype of chemoresistant ovarian tumors. PLoS One. 2012;7: e46858.

52. Di J, Duiveman-de Boer T, Zusterzeel PL, Figdor CG, Massuger LF, Torensma R. The stem cell markers Oct4A, Nanog and c-Myc are expressed in ascites cells and tumor tissue of ovarian cancer patients. Cell Oncol (Dordr). 2013; 36:363-74.

53. Liao J, Qian F, Tchabo N, Mhawech-Fauceglia P, Beck A, Qian Z, Wang X, Huss WJ, Lele SB, Morrison CD, Odunsi K. Ovarian Cancer Spheroid Cells with Stem Cell-Like Properties Contribute to Tumor Generation, Metastasis and Chemotherapy Resistance through Hypoxia-Resistant Metabolism. PLoS One. 2014;9:e84941.

54. Mo L, Bachelder RE, Kennedy M, Chen PH, Chi JT, Berchuck A, Cianciolo G, Pizzo SV. Syngeneic Murine Ovarian Cancer Model Reveals That Ascites Enriches for Ovarian Cancer Stem-Like Cells Expressing Membrane GRP78. Mol Cancer Ther. 2015;14:747-56.

55. Chen W, Dong J, Haiech J, Kilhoffer MC, Zeniou M. Cancer Stem Cell Quiescence and Plasticity as Major Challenges in Cancer Therapy. Stem Cells Int. 2016;2016:1740936.

56. Nassar D, Blanpain C. Cancer Stem Cells: Basic Concepts and Therapeutic Implications. Annu Rev Pathol. 2016;11:47-76.

57. Takeishi S, Nakayama Kl. To wake up cancer stem cells, or to let them sleep, that is the question. Cancer Sci. 2016;107:875-81.

58. Meng E, Long B, Sullivan P, McClellan S, Finan MA, Reed E, Shevde L, Rocconi RP. CD44+/CD24- ovarian cancer cells demonstrate cancer stem cell properties and correlate to survival. Clin Exp Metastasis. 2012;29:939-48.

59. Gao Y, Foster R, Yang X, Feng Y, Shen JK, Mankin HJ, Hornicek FJ, Amiji MM, Duan Z. Up-regulation of CD44 in the development of metastasis, recurrence and drug resistance of ovarian cancer. Oncotarget. 2015;6: 9313-26.

60. Zhang J, Guo X, Chang DY, Rosen DG, Mercado-Uribe I, Liu J. CD133 expression associated with poor prognosis in ovarian cancer. Mod Pathol. 2012;25:456-64.

61. Landen Jr CN, Goodman B, Katre AA, Steg AD, Nick AM, Stone RL, Miller LD, Mejia PV, Jennings NB, Gershenson DM, Bast Jr RC, Coleman RL, LopezBerestein G, Sood AK. Targeting aldehyde dehydrogenase cancer stem cells in ovarian cancer. Mol Cancer Ther. 2010;9:3186-99.

62. Stemberger-Papic S, Vrdoljak-Mozetic D, Ostojic DV, Rubesa-Mihaljevic R, Krigtofic I, Brncic-Fisher A, Kragevic M, Eminovic S. Expression of CD133 and CD117 in 64 Serous Ovarian Cancer Cases. Coll Antropol. 2015;39:745-53.

63. Tan TZ, Miow QH, Huang RY, Wong MK, Ye J, Lau JA, Wu MC, Bin Abdul Hadi LH, Soong R, Choolani M, Davidson B, Nesland JM, Wang LZ, Matsumura N, Mandai M, Konishi I, Goh BC, Chang JT, Thiery JP, Mori S. Functional genomics identifies five distinct molecular subtypes with clinical relevance and pathways for growth control in epithelial ovarian cancer. EMBO Mol Med. 2013;5:983-98.

64. Zhang W, Liu Y, Sun N, Wang D, Boyd-Kirkup J, Dou X, Han JD. Integrating genomic, epigenomic, and transcriptomic features reveals modular signatures underlying poor prognosis in ovarian cancer. Cell Rep. 2013;4: 542-53

65. Sun $Y$, Jia $X$, Wu X. High Expressions of Lgr5 and ALDH1 in Primary Epithelial Ovarian Cancer Correlate with Advanced Tumor Stage and Grade as well as Poor Prognosis of the Patients. Gynecol Obstet Invest. 2016;81:162-8.

66. Kwon AY, Kim Gl, Jeong JY, Song JY, Kwack KB, Lee C, Kang HY, Kim TH, Heo JH, An HJ. VAV3 Overexpressed in Cancer Stem Cells Is a Poor
Prognostic Indicator in Ovarian Cancer Patients. Stem Cells Dev. 2015;24: 1521-35.

67. Ayub TH, Keyver-Paik MD, Debald M, Rostamzadeh B, Thiesler T, Schroder L, Barchet W, Abramian A, Kaiser C, Kristiansen G, Kuhn W, Kubler K. Accumulation of ALDH1-positive cells after neoadjuvant chemotherapy predicts treatment resistance and prognosticates poor outcome in ovarian cancer. Oncotarget. 2015;6:16437-48.

68. Davidson B, Holth A, Hellesylt E, Tan TZ, Huang RY, Trope C, Nesland JM, Thiery JP. The clinical role of epithelial-mesenchymal transition and stem cell markers in advanced-stage ovarian serous carcinoma effusions. Hum Pathol. 2015;46:1-8.

69. Onisim A, lancu M, Vlad C, Kubelac P, Fetica B, Fulop A, Achimas-Cadariu A, Achimas-Cadariu P. Expression of Nestin and CD133 in serous ovarian carcinoma. J BUON. 2016;21:1168-75.

70. Steffensen $K D$, Alvero AB, Yang Y, Waldstrom M, Hui P, Holmberg JC, Silasi DA, Jakobsen A, Rutherford T, Mor G. Prevalence of epithelial ovarian cancer stem cells correlates with recurrence in early-stage ovarian cancer. J Oncol. 2011;2011:620523.

71. Ferrandina G, Bonanno G, Pierelli L, Perillo A, Procoli A, Mariotti A, Corallo M, Martinelli E, Rutella S, Paglia A, Zannoni G, Mancuso S, Scambia G. Expression of CD133-1 and CD133-2 in ovarian cancer. Int J Gynecol Cancer. 2008;18:506-14.

72. Shi $Y Y$, Jiang H. Prognostic role of the cancer stem cell marker CD44 in ovarian cancer: a meta-analysis. Genet Mol Res. 2016;15. doi: 10.4238/gmr. 15038325.

73. Karan Krizanac D, Krasic Arapovic A, Skocibusic S, Pintaric I, Trgo G, Tomic S. CD44 Immunoexpression is Unfavorable Predictor in Ovarian Serous Cancer. Appl Immunohistochem Mol Morphol. 2016. doi:10.1097/pai. 0000000000000427.

74. Hamburger AW, Salmon SE. Primary bioassay of human tumor stem cells. Science. 1977;197:461-3.

75. Buick RN, Mackillop WJ. Measurement of self-renewal in culture of clonogenic cells from human ovarian carcinoma. Br J Cancer. 1981;44: 349-55.

76. Zhang S, Balch C, Chan MW, Lai HC, Matei D, Schilder JM, Yan PS, Huang $\mathrm{TH}$, Nephew KP. Identification and characterization of ovarian cancerinitiating cells from primary human tumors. Cancer Res. 2008;68:4311-20.

77. Chen J, Wang J, Zhang Y, Chen D, Yang C, Kai C, Wang X, Shi F, Dou J. Observation of ovarian cancer stem cell behavior and investigation of potential mechanisms of drug resistance in three-dimensional cell culture. J Biosci Bioeng. 2014;118:214-22.

78. Cheng W, Liu T, Wan X, Gao Y, Wang H. MicroRNA-199a targets CD44 to suppress the tumorigenicity and multidrug resistance of ovarian cancerinitiating cells. FEBS J. 2012;279:2047-59.

79. Du YR, Chen Y, Gao Y, Niu XL, Li YJ, Deng WM. Effects and mechanisms of anti-CD44 monoclonal antibody A3D8 on proliferation and apoptosis of sphere-forming cells with stemness from human ovarian cancer. Int J Gynecol Cancer. 2013;23:1367-75.

80. Bourguignon LY, Peyrollier K, Xia W, Gilad E. Hyaluronan-CD44 interaction activates stem cell marker Nanog, Stat-3-mediated MDR1 gene expression, and ankyrin-regulated multidrug efflux in breast and ovarian tumor cells. J Biol Chem. 2008;283:17635-51.

81. Grass GD, Tolliver LB, Bratoeva M, Toole BP. CD147, CD44, and the epidermal growth factor receptor (EGFR) signaling pathway cooperate to regulate breast epithelial cell invasiveness. J Biol Chem. 2013;288:26089-104.

82. Orian-Rousseau V, Chen L, Sleeman JP, Herrlich P, Ponta H. CD44 is required for two consecutive steps in HGF/c-Met signaling. Genes Dev. 2002;16: 3074-86.

83. Matzke A, Sargsyan V, Holtmann B, Aramuni G, Asan E, Sendtner M, Pace G, Howells N, Zhang W, Ponta H, Orian-Rousseau V. Haploinsufficiency of CMet in cd44-/- mice identifies a collaboration of CD44 and c-Met in vivo. Mol Cell Biol. 2007;27:8797-806.

84. Chang K, Karnad A, Zhao S, Freeman JW. Roles of c-Met and RON kinases in tumor progression and their potential as therapeutic targets. Oncotarget. 2015:6:3507-18.

85. Zhou HY, Pon YL, Wong AS. HGF/MET signaling in ovarian cancer. Curr Mol Med. 2008;8:469-80.

86. Kayastha S, Freedman AN, Piver MS, Mukkamalla J, Romero-Guittierez M, Werness BA. Expression of the hyaluronan receptor, CD44S, in epithelial ovarian cancer is an independent predictor of survival. Clin Cancer Res. 1999;5:1073-6. 
87. Ryabtseva OD, Lukianova NY, Shmurakov YA, Polishchuk LZ, Antipova SV Significance of adhesion molecules expression for estimation of serous ovarian cancer prognosis. Exp Oncol. 2013;35:211-8.

88. Sanchez Lockhart M, Hajos SE, Basilio FM, Mongini C, Alvarez E. Splice variant expression of CD44 in patients with breast and ovarian cancer. Oncol Rep. 2001:8:145-51.

89. Cannistra SA, Abu-Jawdeh G, Niloff J, Strobel T, Swanson L, Andersen J, Ottensmeier C. CD44 variant expression is a common feature of epithelial ovarian cancer: lack of association with standard prognostic factors. J Clin Oncol. 1995;13:1912-21.

90. Ross JS, Sheehan CE, Williams SS, Malfetano JH, Szyfelbein WM, Kallakury BV Decreased CD44 standard form expression correlates with prognostic variables in ovarian carcinomas. Am J Clin Pathol. 2001;116:122-8.

91. Rodriguez-Rodriguez L, Sancho-Torres I, Mesonero C, Gibbon DG, Shih WJ, Zotalis G. The CD44 receptor is a molecular predictor of survival in ovarian cancer. Med Oncol. 2003;20:255-63

92. Sillanpaa S, Anttila MA, Voutilainen K, Tammi RH, Tammi MI, Saarikoski SV, Kosma VM. CD44 expression indicates favorable prognosis in epithelial ovarian cancer. Clin Cancer Res. 2003;9:5318-24.

93. Prochazka L, Tesarik R, Turanek J. Regulation of alternative splicing of CD44 in cancer. Cell Signal. 2014;26:2234-9.

94. Orian-Rousseau V. CD44 Acts as a Signaling Platform Controlling Tumor Progression and Metastasis. Front Immunol. 2015;6:154

95. Thapa R, Wilson GD. The Importance of CD44 as a Stem Cell Biomarker and Therapeutic Target in Cancer. Stem Cells Int. 2016;2016:2087204.

96. Tjhay F, Motohara T, Tayama S, Narantuya D, Fujimoto K, Guo J, Sakaguchi I, Honda R, Tashiro H, Katabuchi H. CD44 variant 6 is correlated with peritoneal dissemination and poor prognosis in patients with advanced epithelial ovarian cancer. Cancer Sci. 2015;106:1421-8.

97. Al-Hajj M, Wicha MS, Benito-Hernandez A, Morrison SJ, Clarke MF. Prospective identification of tumorigenic breast cancer cells. Proc Natl Acad Sci U S A. 2003:100:3983-8

98. Gao MQ, Choi YP, Kang S, Youn JH, Cho NH. CD24+ cells from hierarchically organized ovarian cancer are enriched in cancer stem cells. Oncogene. 2010;29:2672-80

99. Li YH, Sun X, Wang HB. Role of CD24 in anoikis resistance of ovarian cancer cells. J Huazhong Univ Sci Technolog Med Sci. 2015;35:390-6.

100. Davidson B. CD24 is highly useful in differentiating high-grade serous carcinoma from benign and malignant mesothelial cells. Hum Pathol. 2016; $58: 123-7$.

101. Wang YC, Wang JL, Kong X, Sun TT, Chen HY, Hong J, Fang JY. CD24 mediates gastric carcinogenesis and promotes gastric cancer progression via STAT3 activation. Apoptosis. 2014;19:643-56.

102. Wang X, Zhang Y, Zhao Y, Liang Y, Xiang C, Zhou H, Zhang H, Zhang Q, Qing $H$, Jiang B, Xiong $H$, Peng L. CD24 promoted cancer cell angiogenesis via Hsp90-mediated STAT3NEGF signaling pathway in colorectal cancer. Oncotarget. 2016;7:55663-76.

103. Shen YA, Wang CY, Chuang HY, Hwang JJ, Chi WH, Shu CH, Ho CY, Li WY, Chen YJ. CD44 and CD24 coordinate the reprogramming of nasopharyngeal carcinoma cells towards a cancer stem cell phenotype through STAT3 activation. Oncotarget. 2016;7:58351-66.

104. Abubaker K, Luwor RB, Zhu H, McNally O, Quinn MA, Burns CJ, Thompson EW, Findlay JK, Ahmed N. Inhibition of the JAK2/STAT3 pathway in ovarian cancer results in the loss of cancer stem cell-like characteristics and a reduced tumor burden. BMC Cancer. 2014;14:317.

105. Burgos-Ojeda D, Wu R, McLean K, Chen YC, Talpaz M, Yoon E, Cho KR, Buckanovich RJ. CD24+ Ovarian Cancer Cells Are Enriched for CancerInitiating Cells and Dependent on JAK2 Signaling for Growth and Metastasis. Mol Cancer Ther. 2015;14:1717-27.

106. Sharrow AC, Perkins B, Collector MI, Yu W, Simons BW, Jones RJ. Characterization of aldehyde dehydrogenase 1 high ovarian cancer cells: Towards targeted stem cell therapy. Gynecol Oncol. 2016;142:341-8.

107. He QZ, Luo XZ, Wang K, Zhou Q, Ao H, Yang Y, Li SX, Li Y, Zhu HT, Duan T. Isolation and characterization of cancer stem cells from high-grade serous ovarian carcinomas. Cell Physiol Biochem. 2014;33:173-84

108. Yan HC, Fang LS, Xu J, Qiu YY, Lin XM, Huang HX, Han QY. The identification of the biological characteristics of human ovarian cancer stem cells. Eur Rev Med Pharmacol Sci. 2014;18:3497-503.

109. Szotek PP, Pieretti-Vanmarcke R, Masiakos PT, Dinulescu DM, Connolly D, Foster R, Dombkowski D, Preffer F, Maclaughlin DT, Donahoe PK. Ovarian cancer side population defines cells with stem cell-like characteristics and
Mullerian Inhibiting Substance responsiveness. Proc Natl Acad Sci U S A. 2006:103:11154-9.

110. Luo L, Zeng J, Liang B, Zhao Z, Sun L, Cao D, Yang J, Shen K. Ovarian cance cells with the CD117 phenotype are highly tumorigenic and are related to chemotherapy outcome. Exp Mol Pathol. 2011;91:596-602.

111. Abbaspour Babaei M, Kamalidehghan B, Saleem M, Huri HZ, Ahmadipour F. Receptor tyrosine kinase (c-Kit) inhibitors: a potential therapeutic target in cancer cells. Drug Des Devel Ther. 2016;10:2443-59.

112. Chau WK, Ip CK, Mak AS, Lai HC, Wong AS. c-Kit mediates chemoresistance and tumor-initiating capacity of ovarian cancer cells through activation of Wnt/betacatenin-ATP-binding cassette G2 signaling. Oncogene. 2013;32:2767-81.

113. Leone Roberti Maggiore U, Valenzano Menada M, Venturini PL, Ferrero S. The potential of sunitinib as a therapy in ovarian cancer. Expert Opin Investig Drugs. 2013;22:1671-86.

114. du Bois A, Floquet A, Kim JW, Rau J, del Campo JM, Friedlander M, Pignata S, Fujiwara K, Vergote I, Colombo N, Mirza MR, Monk BJ, Kimmig R, RayCoquard I, Zang R, Diaz-Padilla I, Baumann KH, Mouret-Reynier MA, Kim JH, Kurzeder C, Lesoin A, Vasey P, Marth C, Canzler U, Scambia G, Shimada M, Calvert P, Pujade-Lauraine E, Kim BG, Herzog TJ, Mitrica I, Schade-Brittinger C, Wang Q, Crescenzo R, Harter P. Incorporation of pazopanib in maintenance therapy of ovarian cancer. J Clin Oncol. 2014;32:3374-82.

115. Weigel MT, Rath K, Alkatout I, Wenners AS, Schem C, Maass N, Jonat W, Mundhenke C. Nilotinib in combination with carboplatin and paclitaxel is a candidate for ovarian cancer treatment. Oncology. 2014;87:232-45.

116. Singh SK, Clarke ID, Terasaki M, Bonn VE, Hawkins C, Squire J, Dirks PB. Identification of a cancer stem cell in human brain tumors. Cancer Res. 2003;63:5821-8

117. Singh SK, Hawkins C, Clarke ID, Squire JA, Bayani J, Hide T, Henkelman RM, Cusimano MD, Dirks PB. Identification of human brain tumour initiating cells. Nature. 2004:432:396-401.

118. Irollo E, Pirozzi G. CD133: to be or not to be, is this the real question? Am J Transl Res. 2013:5:563-81.

119. Grosse-Gehling P, Fargeas CA, Dittfeld C, Garbe Y, Alison MR, Corbeil D, KunzSchughart LA. CD133 as a biomarker for putative cancer stem cells in solid tumours: limitations, problems and challenges. J Pathol. 2013;229:355-78.

120. Zhou Q, Chen A, Song H, Tao J, Yang H, Zuo M. Prognostic value of cancer stem cell marker CD133 in ovarian cancer: a meta-analysis. Int J Clin Exp Med. 2015:8:3080-8.

121. Curley MD, Therrien VA, Cummings $C L$, Sergent $P A$, Koulouris $C R$, Friel $A M$, Roberts DJ, Seiden MV, Scadden DT, Rueda BR, Foster R. CD133 expression defines a tumor initiating cell population in primary human ovarian cancer. Stem Cells. 2009;27:2875-83.

122. Kryczek I, Liu S, Roh M, Vatan L, Szeliga W, Wei S, Banerjee M, Mao Y, Kotarski J, Wicha MS, Liu R, Zou W. Expression of aldehyde dehydrogenase and CD133 defines ovarian cancer stem cells. Int J Cancer. 2012;130:29-39.

123. Choi YJ, Ingram PN, Yang K, Coffman L, lyengar M, Bai S, Thomas DG, Yoon E, Buckanovich RJ. Identifying an ovarian cancer cell hierarchy regulated by bone morphogenetic protein 2. Proc Natl Acad Sci U S A. 2015:112:E6882-8.

124. Cioffi M, D'Alterio C, Camerlingo R, Tirino V, Consales C, Riccio A, lerano C, Cecere SC, Losito NS, Greggi S, Pignata S, Pirozzi G, Scala S. Identification of a distinct population of CD133(+)CXCR4(+) cancer stem cells in ovarian cancer. Sci Rep. 2015:5:10357.

125. Baba T, Convery PA, Matsumura N, Whitaker RS, Kondoh E, Perry T, Huang Z, Bentley RC, Mori S, Fujii S, Marks JR, Berchuck A, Murphy SK. Epigenetic regulation of CD133 and tumorigenicity of CD133+ ovarian cancer cells. Oncogene. 2009;28:209-18.

126. Kusumbe AP, Mali AM, Bapat SA. CD133-expressing stem cells associated with ovarian metastases establish an endothelial hierarchy and contribute to tumor vasculature. Stem Cells. 2009;27:498-508.

127. Ishiguro T, Sato A, Ohata H, Ikarashi Y, Takahashi RU, Ochiya T, Yoshida M, Tsuda H, Onda T, Kato T, Kasamatsu T, Enomoto T, Tanaka K, Nakagama H, Okamoto K. Establishment and Characterization of an In Vitro Model of Ovarian Cancer Stem-like Cells with an Enhanced Proliferative Capacity. Cancer Res. 2016;76:150-60.

128. Stewart JM, Shaw PA, Gedye C, Bernardini MQ, Neel BG, Ailles LE. Phenotypic heterogeneity and instability of human ovarian tumor-initiating cells. Proc Natl Acad Sci U S A. 2011;108:6468-73.

129. Hermansen SK, Christensen KG, Jensen SS, Kristensen BW. Inconsistent Immunohistochemical Expression Patterns of Four Different CD133 Antibody Clones in Glioblastoma. J Histochem Cytochem. 2011;59:391-407. 
130. Hashimoto K, Aoyagi K, Isobe T, Kouhuji K, Shirouzu K. Expression of CD133 in the cytoplasm is associated with cancer progression and poor prognosis in gastric cancer. Gastric Cancer. 2014;17:97-106.

131. Brescia P, Ortensi B, Fornasari L, Levi D, Broggi G, Pelicci G. CD133 is essential for glioblastoma stem cell maintenance. Stem Cells. 2013;31:857-69.

132. Silva IA, Bai S, McLean K, Yang K, Griffith K, Thomas D, Ginestier C, Johnston C, Kueck A, Reynolds RK, Wicha MS, Buckanovich RJ. Aldehyde dehydrogenase in combination with CD133 defines angiogenic ovarian cancer stem cells that portend poor patient survival. Cancer Res. 2011;71: 3991-4001.

133. Jang JW, Song Y, Kim SH, Kim JS, Kim KM, Choi EK, Kim J, Seo HR. CD133 confers cancer stem-like cell properties by stabilizing EGFR-AKT signaling in hepatocellular carcinoma. Cancer Lett. 2016;389:1-10.

134. Zhu Y, Yu J, Wang S, Lu R, Wu J, Jiang B. Overexpression of CD133 enhances chemoresistance to 5-fluorouracil by activating the PI3KAkt/ p70S6K pathway in gastric cancer cells. Oncol Rep. 2014;32:2437-44

135. Yu CC, Hu FW, Yu CH, Chou MY. Targeting CD133 in the enhancement of chemosensitivity in oral squamous cell carcinoma-derived side population cancer stem cells. Head Neck. 2016;38 Suppl 1:E231-8.

136. Wei Y, Jiang Y, Zou F, Liu Y, Wang S, Xu N, Xu W, Cui C, Xing Y, Liu Y, Cao B, Liu C, Wu G, Ao H, Zhang X, Jiang J. Activation of PI3K/Akt pathway by CD133-p85 interaction promotes tumorigenic capacity of glioma stem cells. Proc Natl Acad Sci U S A. 2013;110:6829-34.

137. Petrillo M, Nero C, Amadio G, Gallo D, Fagotti A, Scambia G. Targeting the hallmarks of ovarian cancer: The big picture. Gynecol Oncol. 2016; 142:176-83

138. Tomita H, Tanaka K, Tanaka T, Hara A. Aldehyde dehydrogenase $1 \mathrm{~A} 1$ in stem cells and cancer. Oncotarget. 2016;7:11018-32.

139. Wang Y, Cardenas H, Fang F, Condello S, Taverna P, Segar M, Liu Y, Nephew KP, Matei D. Epigenetic targeting of ovarian cancer stem cells. Cancer Res. 2014;74:4922-36

140. Condello S, Morgan CA, Nagdas S, Cao L, Turek J, Hurley TD, Matei D. betaCatenin-regulated ALDH1A1 is a target in ovarian cancer spheroids. Oncogene. 2015;34:2297-308.

141. Januchowski R, Wojtowicz K, Sterzynska K, Sosinska P, Andrzejewska M, Zawierucha P, Nowicki M, Zabel M. Inhibition of ALDH1A1 activity decreases expression of drug transporters and reduces chemotherapy resistance in ovarian cancer cell lines. Int J Biochem Cell Biol. 2016;78:248-59.

142. Meng E, Mitra A, Tripathi K, Finan MA, Scalici J, McClellan S, Madeira da Silva $L$, Reed E, Shevde LA, Palle K, Rocconi RP. ALDH1A1 maintains ovarian cancer stem cell-like properties by altered regulation of cell cycle checkpoint and DNA repair network signaling. PLoS One. 2014;9:e107142.

143. Behbod F, Vivanco MD. Side population. Methods Mol Biol. 2015;1293: 73-81.

144. Yasuda K, Torigoe T, Morita R, Kuroda T, Takahashi A, Matsuzaki J, Kochin V, Asanuma H, Hasegawa T, Saito T, Hirohashi Y, Sato N. Ovarian cancer stem cells are enriched in side population and aldehyde dehydrogenase bright overlapping population. PLoS One. 2013;8:e68187.

145. Hu L, McArthur C, Jaffe RB. Ovarian cancer stem-like side-population cells are tumourigenic and chemoresistant. Br J Cancer. 2010;102:1276-83.

146. Boesch M, Zeimet AG, Reimer D, Schmidt S, Gastl G, Parson W, Spoeck F, Hatina J, Wolf D, Sopper S. The side population of ovarian cancer cells defines a heterogeneous compartment exhibiting stem cell characteristics. Oncotarget. 2014;5:7027-39.

147. Kusumbe AP, Bapat SA. Cancer stem cells and aneuploid populations within developing tumors are the major determinants of tumor dormancy. Cancer Res. 2009;69:9245-53.

148. Naik RR, Gardi NL, Bapat SA. Elucidation of molecular and functional heterogeneity through differential expression network analyses of discrete tumor subsets. Sci Rep. 2016;6:25261.

149. Zhang S, Mercado-Uribe I, Xing Z, Sun B, Kuang J, Liu J. Generation of cancer stem-like cells through the formation of polyploid giant cancer cells. Oncogene. 2014;33:116-28.

150. Pece S, Tosoni D, Confalonieri S, Mazzarol G, Vecchi M, Ronzoni S, Bernard L, Viale G, Pelicci PG, Di Fiore PP. Biological and molecular heterogeneity of breast cancers correlates with their cancer stem cell content. Cell. 2010;140: 62-73.

151. Szotek PP, Chang HL, Brennand K, Fujino A, Pieretti-Vanmarcke R, Lo Celso C, Dombkowski D, Preffer F, Cohen KS, Teixeira J, Donahoe PK. Normal ovarian surface epithelial label-retaining cells exhibit stem/progenitor cell characteristics. Proc Natl Acad Sci U S A. 2008;105:12469-73.
152. Wang $Y$, Sacchetti $A$, van Dijk MR, van der Zee $M$, van der Horst PH, Joosten R, Burger CW, Grootegoed JA, Blok LJ, Fodde R. Identification of quiescent, stem-like cells in the distal female reproductive tract. PLoS One. 2012;7: e40691.

153. Ricci F, Bernasconi S, Perego P, Ganzinelli M, Russo G, Bono F, Mangioni C, Fruscio R, Signorelli M, Broggini M, Damia G. Ovarian carcinoma tumorinitiating cells have a mesenchymal phenotype. Cell Cycle. 2012;11:1966-76.

154. Tomao F, Papa A, Strudel M, Rossi L, Lo Russo G, Benedetti Panici P, Ciabatta FR, Tomao S. Investigating molecular profiles of ovarian cancer: an update on cancer stem cells. J Cancer. 2014;5:301-10.

155. Karnezis AN, Cho KR, Gilks CB, Pearce CL, Huntsman DG. The disparate origins of ovarian cancers: pathogenesis and prevention strategies. Nat Rev Cancer. 2017:17:65-74.

156. Eckert MA, Pan S, Hernandez KM, Loth RM, Andrade J, Volchenboum SL, Faber P. Montag A, Lastra R, Peter ME, Yamada SD, Lengyel E. Genomics of Ovarian Cancer Progression Reveals Diverse Metastatic Trajectories Including Intraepithelial Metastasis to the Fallopian Tube Cancer Discov. 2016:6:1342-51.

157. Gamwell LF, Collins O, Vanderhyden BC. The mouse ovarian surface epithelium contains a population of LY6A (SCA-1) expressing progenitor cells that are regulated by ovulation-associated factors. Biol Reprod. 2012;87:80.

158. Flesken-Nikitin A, Hwang Cl, Cheng CY, Michurina TV, Enikolopov G, Nikitin AY. Ovarian surface epithelium at the junction area contains a cancer-prone stem cell niche. Nature. 2013;495:241-5.

159. Ng A, Tan S, Singh G, Rizk P, Swathi Y, Tan TZ, Huang RY, Leushacke $M$, Barker N. Lgr5 marks stem/progenitor cells in ovary and tubal epithelia. Nat Cell Biol. 2014;16:745-57.

160. Snegovskikh V, Mutlu L, Massasa E, Taylor HS. Identification of putative fallopian tube stem cells. Reprod Sci. 2014;21:1460-4.

161. Paik DY, Janzen DM, Schafenacker AM, Velasco VS, Shung MS, Cheng D, Huang J, Witte ON, Memarzadeh S. Stem-like epithelial cells are concentrated in the distal end of the fallopian tube: a site for injury and serous cancer initiation. Stem Cells. 2012;30:2487-97.

162. Yamamoto $Y$, Ning G, Howitt BE, Mehra K, Wu L, Wang X, Hong Y, Kern F, Wei TS, Zhang T, Nagarajan N, Basuli D, Torti S, Brewer M, Choolani M, Mckeon F, Crum CP, Xian W. In vitro and in vivo correlates of physiological and neoplastic human Fallopian tube stem cells. J Pathol. 2016;238:519-30.

163. Bareiss PM, Paczulla A, Wang H, Schairer R, Wiehr S, Kohlhofer U, Rothfuss OC, Fischer A, Perner S, Staebler A, Wallwiener D, Fend F, Fehm T, Pichler B, Kanz L, Quintanilla-Martinez L, Schulze-Osthoff K, Essmann F, Lengerke C. SOX2 expression associates with stem cell state in human ovarian carcinoma. Cancer Res. 2013;73:5544-55.

164. Hellner K, Miranda F, Fotso Chedom D, Herrero-Gonzalez S, Hayden DM, Tearle R, Artibani M, KaramiNejadRanjbar M, Williams R, Gaitskell K, Elorbany S, Xu R, Laios A, Buiga P, Ahmed K, Dhar S, Zhang RY, Campo L, Myers KA, Lozano M, Ruiz-Miro M, Gatius S, Mota A, Moreno-Bueno G, Matias-Guiu X, Benitez J, Witty L, McVean G, Leedham S, Tomlinson I, Drmanac R, Cazier JB, Klein R, Dunne K, Bast Jr RC, Kennedy SH, Hassan B, Lise S, Garcia MJ, Peters BA, Yau C, Sauka-Spengler T, Ahmed AA. Premalignant SOX2 overexpression in the fallopian tubes of ovarian cancer patients: Discovery and validation studies. EBioMedicine. 2016:10:137-49.

165. Plaks V, Kong N, Werb Z. The cancer stem cell niche: how essential is the niche in regulating stemness of tumor cells? Cell Stem Cell. 2015;16:225-38.

166. Melzer C, von der Ohe J, Lehnert H, Ungefroren H, Hass R. Cancer stem cell niche models and contribution by mesenchymal stroma/stem cells. Mol Cancer. 2017;16:28.

167. Ng A, Barker N. Ovary and fimbrial stem cells: biology, niche and cancer origins. Nat Rev Mol Cell Biol. 2015;16:625-38.

168. Kretzschmar K, Clevers H. Organoids: Modeling Development and the Stem Cell Niche in a Dish. Dev Cell. 2016:38:590-600.

169. Kessler M, Hoffmann K, Brinkmann V, Thieck O, Jackisch S, Toelle B, Berger $H$ Mollenkopf HJ, Mangler M, Sehouli J, Fotopoulou C, Meyer TF. The Notch and Wnt pathways regulate stemness and differentiation in human fallopian tube organoids. Nat Commun. 2015;6:8989.

170. Kenny HA, Chiang CY, White EA, Schryver EM, Habis M, Romero IL, Ladanyi A, Penicka CV, George J, Matlin K, Montag A, Wroblewski K, Yamada SD, Mazar AP, Bowtell D, Lengyel E. Mesothelial cells promote early ovarian cancer metastasis through fibronectin secretion. J Clin Invest. 2014;124: 4614-28.

171. Nieman KM, Kenny HA, Penicka CV, Ladanyi A, Buell-Gutbrod R, Zillhardt MR Romero IL, Carey MS, Mills GB, Hotamisligil GS, Yamada SD, Peter ME, Gwin 
K, Lengyel E. Adipocytes promote ovarian cancer metastasis and provide energy for rapid tumor growth. Nat Med. 2011;17:1498-503.

172. Kipps E, Tan DS, Kaye SB. Meeting the challenge of ascites in ovarian cancer: new avenues for therapy and research. Nat Rev Cancer. 2013;13:273-82.

173. Kim S, Kim B, Song YS. Ascites modulates cancer cell behavior, contributing to tumor heterogeneity in ovarian cancer. Cancer Sci. 2016;107:1173-8.

174. Rizzo S, Hersey JM, Mellor P, Dai W, Santos-Silva A, Liber D, Luk L, Titley I, Carden CP, Box G, Hudson DL, Kaye SB, Brown R. Ovarian cancer stem celllike side populations are enriched following chemotherapy and overexpress EZH2. Mol Cancer Ther. 2011;10:325-35.

175. Kryczek I, Grybos M, Karabon L, Klimczak A, Lange A. IL-6 production in ovarian carcinoma is associated with histiotype and biological characteristics of the tumour and influences local immunity. Br J Cancer. 2000;82:621-8.

176. Giuntoli 2nd RL, Webb TJ, Zoso A, Rogers O, Diaz-Montes TP, Bristow RE, Oelke M. Ovarian cancer-associated ascites demonstrates altered immune environment: implications for antitumor immunity. Anticancer Res. 2009;29: 2875-84.

177. Lane D, Matte I, Rancourt C, Piche A. Prognostic significance of IL-6 and IL-8 ascites levels in ovarian cancer patients. BMC Cancer. 2011;11:210.

178. Lane D, Matte I, Garde-Granger P, Laplante C, Carignan A, Rancourt C, Piche A. Inflammation-regulating factors in ascites as predictive biomarkers of drug resistance and progression-free survival in serous epithelial ovarian cancers. BMC Cancer. 2015;15:492.

179. Kim S, Gwak H, Kim HS, Kim B, Dhanasekaran DN, Song YS. Malignant ascites enhances migratory and invasive properties of ovarian cancer cells with membrane bound IL-6R in vitro. Oncotarget. 2016;7:83148-59.

180. Bharti R, Dey G, Mandal M. Cancer development, chemoresistance, epithelial to mesenchymal transition and stem cells: A snapshot of IL-6 mediated involvement. Cancer Lett. 2016;375:51-61.

181. Saini U, Naidu S, ElNaggar AC, Bid HK, Wallbillich JJ, Bixel K, Bolyard C, Suarez AA, Kaur B, Kuppusamy P, Hays J, Goodfellow PJ, Cohn DE, Selvendiran K. Elevated STAT3 expression in ovarian cancer ascites promotes invasion and metastasis: a potential therapeutic target. Oncogene. 2017;36:168-81.

182. Barbolina MV, Burkhalter RJ, Stack MS. Diverse mechanisms for activation of Wnt signalling in the ovarian tumour microenvironment. Biochem J. 2011; 437:1-12.

183. Arend RC, Londono-Joshi Al, Samant RS, Li Y, Conner M, Hidalgo B, Alvarez RD, Landen CN, Straughn JM, Buchsbaum DJ. Inhibition of Wnt/beta-catenin pathway by niclosamide: a therapeutic target for ovarian cancer. Gynecol Oncol. 2014;134:112-20.

184. Walters Haygood CL, Arend RC, Londono-Joshi A, Kurpad C, Katre AA, Conner MG, Landen Jr CN, Straughn Jr JM, Buchsbaum DJ. Ovarian cancer ascites stem cell population compared to primary tumor. Gynecol Oncol. 2014;133:122.

185. Chau WK, Ip Ck Fau - Mak ASC, Mak As Fau - Lai HC, Lai HC Fau - Wong AST, Wong AS. c-Kit mediates chemoresistance and tumor-initiating capacity of ovarian cancer cells through activation of Wnt/beta-catenin-ATPbinding cassette G2 signaling. Oncogene. 2013:32:2767-81.

186. Mariya T, Hirohashi Y, Torigoe T, Tabuchi Y, Asano T, Saijo H, Kuroda T, Yasuda K, Mizuuchi M, Saito T, Sato N. Matrix metalloproteinase-10 regulates stemness of ovarian cancer stem-like cells by activation of canonical Wnt signaling and can be a target of chemotherapy-resistant ovarian cancer. Oncotarget. 2016;7:26806-22.

187. Boone JD, Arend RC, Johnston BE, Cooper SJ, Gilchrist SA, Oelschlager DK, Grizzle WE, McGwin Jr G, Gangrade A, Straughn Jr JM, Buchsbaum DJ. Targeting the Wnt/beta-catenin pathway in primary ovarian cancer with the porcupine inhibitor WNT974. Lab Invest. 2016;96:249-59.

188. Arend RC, Londono-Joshi Al, Gangrade A, Katre AA, Kurpad C, Li Y, Samant RS, Li PK, Landen CN, Yang ES, Hidalgo B, Alvarez RD, Straughn JM, Forero A, Buchsbaum DJ. Niclosamide and its analogs are potent inhibitors of Wnt/ beta-catenin, mTOR and STAT3 signaling in ovarian cancer. Oncotarget. 2016;7:86803-15.

\section{Submit your next manuscript to BioMed Central and we will help you at every step:}

- We accept pre-submission inquiries

- Our selector tool helps you to find the most relevant journal

- We provide round the clock customer support

- Convenient online submission

- Thorough peer review

- Inclusion in PubMed and all major indexing services

- Maximum visibility for your research

Submit your manuscript at www.biomedcentral.com/submit
C Biomed Central 